Institut für Tierernährung und Diätetik

der Vetsuisse-Fakultät Universität Zürich

Direktorin: Prof. Dr. med. vet. Annette Liesegang

Arbeit unter wissenschaftlicher Betreuung von

Prof. Dr. med. vet. Annette Liesegang

\title{
Effects of Diets differing in Dietary Cation-Anion Difference and Calcium Concentration on Calcium Homeostasis in Neutered Male Sheep
}

\section{Inaugural-Dissertation}

zur Erlangung der Doktorwürde der

Vetsuisse-Fakultät Universität Zürich

vorgelegt von

\section{Johanna Rosa Berndine Freitag}

\author{
Tierärztin \\ aus Vechta, Deutschland
}

genehmigt auf Antrag von

Prof. Dr. med. vet. Annette Liesegang, Referentin 



\section{Inhaltsverzeichnis}

Summary 5

\begin{tabular}{ll} 
Zusammenfassung & 6 \\
\hline
\end{tabular}

\begin{tabular}{lr} 
Manuskript & $\mathbf{7}$ \\
\hline Abstract & 8
\end{tabular}

\begin{tabular}{lr}
\hline Introduction & 9
\end{tabular}

\begin{tabular}{lr}
\hline Materials and Methods & 11
\end{tabular}

\begin{tabular}{lr}
\hline Results & 23
\end{tabular}

\begin{tabular}{ll}
\hline Discussion & 37
\end{tabular}

\begin{tabular}{ll}
\hline Conclusions & 42 \\
\hline
\end{tabular}

Acknowledgements $\quad 42$

\begin{tabular}{ll}
\hline Conflict of Interest & 43 \\
\hline
\end{tabular}

\begin{tabular}{ll} 
References & 43 \\
\hline
\end{tabular}

Danksagung

Curriculum Vitae 


\section{Summary}

The aim of the present study was to demonstrate basic effects of negative dietary cation-anion difference (DCAD) diets against a background of different calcium (Ca) supplies in a sheep model. Twenty-three male castrated East Friesian milk sheep were randomly assigned to four different feeding groups: The ration of each group was either high or low in DCAD (highDCAD/lowDCAD) combined with adequate or restricted $\mathrm{Ca}$ supply (nCa/lowCa). At baseline, serum and urine was collected from all sheep and a peripheral quantitative computed tomography (pQCT) of the left metatarsus was performed. After a 14-day adaptation period to the different diets, urine, faeces and serum were collected on days $0,4,7,14$, and 22, and pQCT was performed on days 0 and 22. LowDCAD was significantly associated with lower urine $\mathrm{pH}$, higher urinary $\mathrm{Ca}$ excretion, higher ionized $\mathrm{Ca}$ in blood, and higher serum $\mathrm{Ca}$ concentrations. Blood $\mathrm{pH}$ and bone parameters did not differ significantly between groups. It is unclear from which compartment the high amounts of $\mathrm{Ca}$ excreted with urine in the lowDCAD groups originated. Interestingly, lowDCAD resulted in higher renal mRNA abundance of parathyroid hormone receptor (PTHR) but unaffected mRNA abundance of Ca transporters. As neither renal abundance of these transporters nor $\mathrm{Ca}$ excretion were influenced by dietary $\mathrm{Ca}$ supply, our results support the hypothesis that increased urinary $\mathrm{Ca}$ observed with low DCAD diets represents a loss rather than an excretion of surplus $\mathrm{Ca}$.

Key words: calcium, dietary cation-anion difference, hypocalcaemia, parathyroid hormone receptor, sheep 


\section{Zusammenfassung}

Das Ziel der vorliegenden Studie war, grundlegende Effekte von Rationen mit negativer Kationen-Anionen Bilanz (DCAD) in Abhängigkeit von der Kalzium(Ca)-Versorgung in einem Schafmodell zu demonstrieren. Dreiundzwanzig männlich kastrierte Ostfriesische Milchschafe wurden zufällig vier verschiedenen Fütterungsgruppen zugeordnet: highDCAD und lowDCAD kombiniert mit bedarfsdeckender oder eingeschränkter Ca-Versorgung (nCa/lowCa). Von allen Schafen wurde Serum und Urin gewonnen und eine periphere quantitative Computertomographie (pQCT) des linken Metatarsus durchgeführt. Nach einer 14-tägigen Anfütterungsphase wurden Urin, Kot und Serum an den Tagen 0, 4, 7, 14 und 22 gesammelt. pQCT wurde an den Tagen 0 und 22 durchgeführt. LowDCAD war mit einem signifikant niedrigeren Urin-pH, einer höheren Urin-Ca-Ausscheidung, höheren ionisiertem $\mathrm{Ca}$ und Serum-Ca-Konzentrationen verbunden. Blut-pH und Knochenparameter unterschieden sich nicht signifikant zwischen den Gruppen. Es ist unklar, woher die hohen mit lowDCAD in den Urin ausgeschiedenen Ca-Mengen stammten. LowDCAD führte zu einer höheren renalen mRNA-Abundanz des Parathormonrezeptors (PTHR), aber zu keiner Veränderung der mRNAAbundanz von Ca-Transportern. Da weder die renale Abundanz dieser Transporter noch die Ca-Ausscheidung durch die Ca-Aufnahme beeinflusst wurde, unterstützen unsere Ergebnisse die Hypothese, dass das mit lowDCAD in den Urin ausgeschiedene Ca eher einen Verlust als eine Ausscheidung von überschüssigem Ca darstellt.

Schlüsselwörter: Kalzium, negative Kationen-Anionen Bilanz, Hypocalcämie, Parathormonrezeptor, Schafe 


\section{Manuskript}

Diese Arbeit wurde im Journal of Dairy Science publiziert: Journal of Dairy Science (2021), doi: https://doi.org/10.3168/jds.2021-20334

Effects of Diets differing in Dietary Cation-Anion Difference and Calcium Concentration on Calcium Homeostasis in Neutered Male Sheep

J. R. B. Freitag, ${ }^{1,2}$ M. R. Wilkens, ${ }^{3}$ A. S. Muscher-Banse, ${ }^{3}$ K. Gerstner, ${ }^{1}$ N. Schnepel, ${ }^{3}$ P. R. Torgerson, ${ }^{4}$ and A. Liesegang ${ }^{1,2,5, *}$

${ }^{1}$ Institute of Animal Nutrition, Vetsuisse-Faculty, University of Zurich, Switzerland

${ }^{2}$ Centre for Clinical Studies, Vetsuisse-Faculty, University of Zurich, Switzerland

${ }^{3}$ Institute for Physiology and Cell Biology, University of Veterinary Medicine, Foundation Hannover, Germany

${ }^{4}$ Vetsuisse Faculty, Section of Veterinary Epidemiology, University of Zurich, Zurich, Switzerland

${ }^{5}$ Centre for Applied Biotechnology and Molecular Medicine, University of Zurich, Switzerland

*Corresponding author: Prof. Dr. med. vet. Annette Liesegang, Institute of Animal Nutrition, Vetsuisse-Faculty, University of Zurich, Winterthurerstrasse 270, CH-8057 Zürich, Phone: +4144 63588 23, Fax: +41 44635 89 39, Mail: aliese@ nutrivet.uzh.ch 


\begin{abstract}
Feeding low dietary cation-anion difference (DCAD) diets is one strategy to prevent milk fever in cows. The mechanism of action as well as whether the calcium (Ca) supply of such diets combined with this feeding regimen should meet the requirements, are still unclear. Small ruminants are commonly used as models for cows. The goal of the present study was to demonstrate basic effects of DCAD against a background of different Ca supplies in a sheep model. Twenty-three male castrated East Friesian milk sheep, aged 11-12 months, were randomly assigned to four different feeding groups. The ration of each group was either high or low in DCAD (highDCAD/lowDCAD) combined with adequate or restricted Ca supply (nCa/lowCa). At baseline, serum and urine was collected from all sheep and a peripheral quantitative computed tomography (pQCT) of the left metatarsus was performed. After a 14day adaptation period to the different diets, the experiment started (day 0). Urine, faeces and serum were collected on days $0,4,7,14$, and 22, and pQCT was performed on days 0 and 22 . On day 22, the sheep were sacrificed and sampled for functional studies. LowDCAD was significantly associated with lower urine $\mathrm{pH}$, higher urinary $\mathrm{Ca}$ excretion, higher ionized $\mathrm{Ca}$ in blood, and higher serum Ca concentrations. Blood $\mathrm{pH}$ and bone parameters did not differ significantly between groups. It is unclear from which compartment the high amounts of $\mathrm{Ca}$ excreted with urine in the lowDCAD groups originated. Interestingly, lowDCAD resulted in higher renal mRNA abundance of parathyroid hormone receptor (PTHR) but unaffected mRNA abundance of $\mathrm{Ca}$ transporters. As neither renal abundance of these transporters nor Ca excretion were influenced by dietary Ca supply, our results support the hypothesis that increased urinary Ca observed with low DCAD diets represents a loss rather than an excretion of surplus Ca.
\end{abstract}

Key words: calcium, dietary cation-anion difference, hypocalcaemia, parathyroid hormone receptor, sheep 


\section{INTRODUCTION}

Adapting to the enormous calcium (Ca) demand and maintaining required $\mathrm{Ca}$ plasma concentrations in late gestation, or at the initiation of lactation, is challenging for many mammals including ruminants. The challenge mainly arises in late gestation due to the calcification of the foetal skeleton, and/or after birth due to excessive Ca losses via milk; the former is more often observed in sheep, and the latter in dairy cows and goats (Oetzel et al. 1988, Pugh 2002, Brozos et al., 2011). Nevertheless, at the time of suddenly increased Ca demand, Ca homeostasis mechanisms are not fully effective. Some studies suggest that cows require adaptation periods of $48 \mathrm{~h}$ (Goff et al., 1986; Martin-Tereso and Verstegen, 2011). Consequently, with a prevalence of $49 \%$ (resp. 5.7\%) in the animals starting the $3^{\text {rd }}$ lactation, the risk of subclinical (resp. clinical) hypocalcaemia (milk fever, parturient paresis) remains high in German dairy herds (Venjakob et al., 2017). Hypocalcaemia is known to be a gateway disorder predisposing the animals for different secondary diseases such as mastitis, retained fetal membranes, displaced abomasum, dystocia, and ketosis (Curtis et al., 1983; Goff, 2008; Martinez et al., 2012), resulting in animal welfare issues as well as large financial expenses.

In the last decades, many strategies have been proposed to prevent milk fever and subclinical hypocalcemia. The method of feeding anion-rich diets, first recommended by Ender et al. (1971) has received considerable attention in the past (Block, 1984; DeGaris and Lean, 2008; Goff, 2008). Feeding a diet with dietary cation-anion difference (DCAD) values between -50 and $-150 \mathrm{mEq} / \mathrm{kg} \mathrm{DM}$ during the last $10-28$ days of gestation results in a higher intestinal absorption of the "strong" anions in comparison with their corresponding cations (Horst et al., 1997; DeGaris and Lean, 2008). This causes a compensated metabolic acidosis, increasing the sensitivity of target tissues to parathyroid hormone (PTH), thus increasing the available $\mathrm{Ca}$ in blood (Goff et al., 1991; 2014). Furthermore, the metabolic acidosis generates a hypercalciuria as a result of an increased $\mathrm{Ca}$ clearance from the blood, and thus $\mathrm{Ca}$ fluxes are increased systemically. Another strategy is feeding Ca restricted diets 3 weeks prepartum and is based on 
the principle above: low $\mathrm{Ca}$ intake creates a $\mathrm{Ca}$ deficit and prompts metabolic adaptation of renal, intestinal and bone tissue via PTH and 1,25-dihydroxyvitamin D to restore $\mathrm{Ca}$ homeostasis (Martin-Tereso and Verstegen, 2011). However, many details of the basic mechanisms caused by low DCAD diets, as well as restrictive Ca diets are still unclear in ruminants. Moreover, different studies considering the incidence of hypocalcaemia and analyzing the influence of dietary Ca levels on DCAD came to controversial conclusions (Horst et al., 1997; Lean et al., 2006; Liesegang et al., 2007; 2008). Additionally, there are conflicting reports of the apparent Ca digestibility in cows fed diets low in DCAD (Leclerc and Block, 1989; Abu Damir et al., 1994; Liesegang et al., 2007), which might be associated with different dietary Ca levels (Lomba et al., 1978).

It was the purpose of our experiment to study basic effects of different DCADs along with varying $\mathrm{Ca}$ supply on $\mathrm{Ca}$ homeostatic mechanisms in a sheep model. The sheep serves as a small model animal and represents the dairy cow in this experiment, where milk fever is of greater economic interest. Our main objective was to prove the hypotheses that feeding a diet low in DCAD increases the fractional excretion (FE) of Ca independently of dietary Ca supply, while Ca transport mechanisms and apparent digestibility are altered by both factors, DCAD and dietary Ca. It was of particular interest to test if the abundance of receptors and transport proteins crucial for Ca homeostatic mechanisms are affected by the different experimental diets. In order to test these hypotheses, we created four different sheep feeding groups, which were provided diets differing in DCAD (high/low) and Ca (normal/low), measured relevant $\mathrm{Ca}$ associated parameters including ruminal and jejunal Ca fluxes via Ussing chamber technique and analyzed renal and intestinal $\mathrm{Ca}$ homeostasis mechanisms on RNA level. To avoid any interferences with the reproductive cycle and in order to focus the DCAD research on functional basic effects, we used wethers: neutered, male sheep. 


\section{MATERIALS AND METHODS}

This study was approved by the Cantonal Veterinary Office of Zurich, based on the animal welfare law of Switzerland (approval ZH 092/16).

\section{Animals}

Twenty-three male castrated East Friesian milk sheep, aged 11-12 months, were randomly assigned to four different feeding groups. The concentrate of each group was modified for DCAD and Ca content. Groups were kept in pens on wood shavings with free access to water and a salt lick stone (AGROSAL D-Heilbronn; saline including 38.5\% sodium, additive iodine $100 \mathrm{mg} / \mathrm{kg}$ ) with a photoperiod from 7 am to $7 \mathrm{pm}$. Prior to the experiment (from weaning until the start of the experiment) all sheep were fed a conventional diet consisting of hay and concentrate (Melior 9 2921C Combifloc, Meliofeed AG, Herzogenbuchsee, Switzerland) according to the requirements. DCAD was not calculated for that diet. Day-14 represents the start of the 14-day adaptation period, in which the amount of experimental concentrate and straw was slowly increased to the experimental level for each group. After the 14 day adaptation period, the experiment started (day0). Day-14 was used as the baseline throughout the experiment, as all animals received the same diet until that time.The sheep were sacrificed after 21 days on the full experimental diet. Weight (W) and Body Condition Score (BCS) were checked once per week. The sheep were shorn before the experiment started.

\section{Feeding Regimen}

The diet consisted of straw and concentrate. After lab analysis of the contents of straw, four special concentrates were designed, containing different DCAD values and Ca concentrations (Table 1) by using the following formula for the DCAD: DCAD $=\left[\left(\mathrm{Na}^{+}+\mathrm{K}^{+}\right)-\left(\mathrm{Cl}^{-}+\mathrm{SO}_{4}{ }^{2-}\right)\right]$ in $\mathrm{mEq} / \mathrm{kg} \mathrm{DM}$ (Wang and Beede, 1992).

Each group's diet met the minimum nutritional requirement recommended by Agroscope (Agroscope, 2016), except Ca in the low Ca groups (38.5\% of recommended requirement, Table $1)$. 
Table 1. Daily allowance (kilogram dry matter) and chemical composition ( $\mathrm{g} / \mathrm{kg}$ dry matter) of the feed mixtures used (complete diet). Different sheep feeding groups received either a diet high or low in dietary cation-anion difference (highDCAD/ lowDCAD) combined with normal or low Calcium $(\mathrm{Ca})$ supply (nCa/ lowCa)

\begin{tabular}{|c|c|c|c|c|}
\hline $\begin{array}{l}\text { Intake } \\
{[\mathrm{g} / \mathrm{kg} \mathrm{DM}]}\end{array}$ & highDCADnCa & highDCADlowCa & lowDCADnCa & lowDCADlowCa \\
\hline \multicolumn{5}{|l|}{ Daily allowance } \\
\hline NEL (MJ/kg TS) & 9.42 & 9.26 & 9.52 & 9.50 \\
\hline Straw & 718.7 & 718.7 & 718.7 & 718.7 \\
\hline Concentrate & 625.3 & 491.9 & 622.6 & 571.2 \\
\hline Barley flakes & 124.0 & 212.5 & 141.7 & 177.1 \\
\hline $\begin{array}{l}\text { Anionic salt }(\mathrm{g} / \mathrm{d}) \\
\text { (ammonium chloride) }\end{array}$ & & & 3.0 & 3.0 \\
\hline \multicolumn{5}{|l|}{$\begin{array}{l}\text { Chemical composition } \\
\text { (complete diet) }\end{array}$} \\
\hline Dry matter $[\mathrm{g} / \mathrm{kg}$ oS $]$ & 924.3 & 924.9 & 891.1 & 922.7 \\
\hline Crude ash & 89.1 & 74.2 & 96.1 & 83.5 \\
\hline Crude protein & 110.4 & 104.1 & 115.5 & 110.0 \\
\hline Crude fat & 23.9 & 22.5 & 24.8 & 23.7 \\
\hline Crude fibre $(\mathrm{CF})$ & 236.7 & 241.4 & 250.5 & 244.4 \\
\hline $\mathrm{ADF}^{2}$ & 312.1 & 317.4 & 327.8 & 320.8 \\
\hline $\mathrm{NDF}^{3}$ & 509.7 & 517.1 & 531.5 & 521.8 \\
\hline $\mathrm{Ca}$ & 6.8 & 2.6 & 6.9 & 2.6 \\
\hline $\mathrm{Na}$ & 2.6 & 2.8 & 2.3 & 2.2 \\
\hline K & 24.6 & 22.7 & 12.0 & 11.5 \\
\hline $\mathrm{P}$ & 3.3 & 3.4 & 3.4 & 3.3 \\
\hline S & 8.8 & 8.1 & 9.1 & 8.4 \\
\hline $\mathrm{Cl}$ & 1.6 & 1.6 & 6.2 & 5.5 \\
\hline DCAD $[\mathrm{meq} / \mathrm{kg} \mathrm{DM}]^{1}$ & 150 & 152 & -335 & -289 \\
\hline VitD3 (IE/kg DM) & 508.8 & 400.1 & 506.4 & 459.2 \\
\hline $\mathrm{ADL}^{4}(\% \mathrm{DM})$ & 4.33 & 4.32 & 4.18 & 4.35 \\
\hline
\end{tabular}

${ }^{1}$ DCAD, dietary cation-anion difference, calculated as $\left[\left(\right.\right.$ meq Na$/ / \mathrm{kg} \mathrm{DM}+$ meq K$\left.{ }^{+} / \mathrm{kg} \mathrm{DM}\right)-$ (meq $\mathrm{Cl}^{-} / \mathrm{kg} \mathrm{DM}+$ meq SO4${ }^{2-} / \mathrm{kg} \mathrm{DM}$ )] (Wang and Beede, 1992).

${ }^{2} \mathrm{ADF}$, acid detergent fibre $[\mathrm{g} / \mathrm{kg} \mathrm{DM}]=1.14 \mathrm{CF}[\mathrm{g} / \mathrm{kg} \mathrm{DM}]+$ 42.2, $(\mathrm{r}=0.93)$ (Kamphues et al., 2004).

${ }^{3} \mathrm{NDF}$, neutral detergent fibre $[\mathrm{g} / \mathrm{kg} \mathrm{DM}]=1.58 \mathrm{CF}[\mathrm{g} / \mathrm{kg} \mathrm{DM}]+135.7$, $(\mathrm{r}=$ 0.88) (Kamphues et al., 2004).

${ }^{4}$ ADL, acid detergent lignin (van Soest et al., 1991). 
The concentrate was manufactured at Agroscope, Posieux, Switzerland. The sheep were fed individually according to weight and group, twice per day out of plastic buckets tied up during feed intake. The diet was calculated such that the daily weight gain of the sheep was $150 \mathrm{~g}$.

\section{Sampling Regimen}

Before the adaptation period (day-14), serum and urine were collected from all sheep. Furthermore, a peripheral quantitative computed tomography (pQCT) of the left metatarsus was performed. After the 14-day adaptation period to the new diet, the experiment started (day0). Urine, faeces and serum were collected on days $0,4,7,14$ and 22 and pQCT was performed on days 0 and 22 .

Spontaneous urine and faecal samples were collected in the morning (before feeding) in blank plastic cups and frozen at $-20^{\circ} \mathrm{C}$ until analysis. The urine $\mathrm{pH}$ was measured directly after sampling by a pH-meter (827 pH lab, Metrohm AG, Herisau, Switzerland).

Blood (2x 5ml) was drawn using a Vacutainer system (BD Vacutainer, SST II Advance, Becton, Dickinson and Company, NJ, USA) after urine sampling from a vena jugularis externa, allowed to clot at room temperature and centrifuged 30 min after withdrawal (Sigma Laborzentrifugen Type $2-15,3,000 \times g, 15 \mathrm{~min}$, room temperature). Serum was pipetted into plastic containers and stored at $-20^{\circ} \mathrm{C}$ and $-80^{\circ} \mathrm{C}$ until analyses were performed.

On day 22 the animals were sacrificed at the slaughterhouse of the Tierspital Zurich. Different samples were collected immediately post mortem: the rumen was dissected and a piece of the ventral rumen wall was manually stripped from the underlying submucosal and muscle layers, rinsed in physiological saline $(0.9 \%)$, and placed in buffer solution (please refer to Wilkens et al., 2011) until it was finally mounted into Ussing chambers. Jejunum (central part) was longitudinally cut, washed in physiological saline, and was also mounted into Ussing chambers. Directly after opening the rumen a sample of ruminal fluid was collected, centrifuged $(3,000 \mathrm{x}$ $g, 15 \mathrm{~min}$, room temperature), and stored at $-20^{\circ} \mathrm{C}$. Renal cortex, duodenal and jejunal mucosa were collected, frozen in liquid nitrogen, and stored at $-80^{\circ} \mathrm{C}$ until further analysis. 
The left metatarsus was isolated from the adherent tissue and stored at $-20^{\circ} \mathrm{C}$. The ionized blood $\mathrm{Ca}$ and blood $\mathrm{pH}$ levels were measured by i-STAT® Analyzer (Abbott Point of Care Inc., Princeton, $N J$, USA) according to manufacturer's instructions immediately after sacrifice.

\section{Analyses of Serum, Urine and Ruminal Fluid}

Concentrations of (Ca) in serum, urine and ruminal fluid were analyzed by flame technique of atomic absorption spectrometry using High- Resolution Continuum Source Atomic Absorption Spectrometer ContrAA 700 (Analytik Jena, Germany). The measurements were performed at $\lambda$ $=422.7 \mathrm{~nm}$.

Analysis for phosphate (PHOS) and creatinine (Crea) was performed via colorimetry using an autoanalyzer (Cobas Mira Roche-autoanalyzer, F. Hoffman-La Roche Ltd., Basel, Switzerland) and commercial test kits (PHOS, testkit PHOS DIA00620, ammonium molybdate, Diatools AG, Villmergen, Switzerland, intra- and interassay coefficients of variation 0.86 and $1.07 \%$, sensitivity $0.07 \mathrm{mmol} / \mathrm{L}$; Crea, testkit CREA JAFFE DIA00540, Diatools AG, Villmergen, Switzerland, intra- and interassay coefficients of variation 0.83 and $0.85 \%$, sensitivity 18 $\mu \mathrm{mol} / \mathrm{L})$.

The following parameters were analyzed by using commercial kits as described by Liesegang et al. (2003): Osteocalcin (OC, MikroVue Osteocalcin EIA Kit; Quidel Corporation, San Diego, CA, intra- and interassay coefficients of variation 4.8 and $4.8 \%$, sensitivity $0.45 \mathrm{ng} / \mathrm{mL}$ ), serum Crosslaps (SCL Serum CrossLaps (CTX-I) ELISA, Immunodiagnostic Systems GmbH, intra- and interassay coefficients of variation 1.7 and $2.5 \%$, respectively, sensitivity 0.020 ng/mL), 1,25vitD (1.25-Dihydroxy Vitamin D RIA, Immunodiagnostics Systems GmbH, intraand interassay coefficients of variation 9.1 and $9.6 \%$, respectively, sensitivity $<8$ pmol/L; cross reactivity with 1,25-dihydroxyvitamin $\mathrm{D}_{3} 100 \%$, with 1,25-dihydroxyvitamin $\mathrm{D}_{2} 97 \%$, with 24,25-dihydroxyvitamin $\mathrm{D}_{3}$ and 25-hydroxyvitamin $\mathrm{D}_{3}<0.01 \%$ ), 25vitD (25-Hydroxy Vitamin D RIA, Immunodiagnostic Systems GmbH, Frankfurt am Main, Germany, intra- and interassay coefficients of variation 5.3 and $8.1 \%$, respectively sensitivity $<3 \mathrm{nmol} / \mathrm{L}$; cross reactivity with 
25-hydroxyvitamin $\mathrm{D}_{3}$ and 24,25-dihydroxyvitamin $\mathrm{D}_{3} 100 \%$, with 25-hydroxyvitamin $\mathrm{D}_{2}$ $75 \%$, with vitamin $\mathrm{D}_{3}<0.01 \%$, and with vitamin $\left.\mathrm{D}_{2}<0.3 \%\right)$.

Fractional excretion $(\mathbf{F E})$ of Ca was calculated using the following formula: $\mathrm{FE}(\mathrm{Ca})=(\mathrm{Crea}$ serum $[\mu \mathrm{M}]$ x Ca urine $[\mu \mathrm{M}]) /($ Crea urine $[\mu \mathrm{M}]$ x Ca serum $[\mu \mathrm{M}])$ x $100[\%]$. FE of PHOS was calculated the same way, but with PHOS concentrations instead of Ca.

\section{Analysis of Feed and Faeces}

To determine DM and for further analyses, feed and faeces were dried at $103^{\circ} \mathrm{C}$ in aluminium bowls in a drying oven until weight was constant, ashed at $550^{\circ} \mathrm{C}$ in a muffle furnace, grinded with a feed mill (Retsch, Type ZM200, 10000 rpm; Retsch GmbH, Haan, Germany) and hydrolyzed in hydrochloric acid $(0.8 \%)$. The mineral contents $(\mathrm{Ca}, \mathrm{P})$ of feed and faeces were analyzed using the same technique as in serum, urine and ruminal fluid.

Acid detergent lignin (ADL) was analyzed as described by van Soest et al. (1991). Acid detergent fiber (ADF) and neutral detergent fiber (NDF) were calculated as described in Kamphues et al., 2004.

Feedstuffs were analyzed for crude ash, crude protein, crude fat and crude fiber by the standardized proximate analysis, according to the VDLUFA method book III (Naumann and Bassler, 1997).

Apparent digestibility (AD) of $\mathrm{Ca}$ and PHOS was estimated by indicator method, using ADL as internal marker and following formula (Stangl 2014): AD $(\%)=100-[(\%$ indicator in feed $/ \%$ indicator in faeces) $\mathrm{x}(\%$ mineral in faeces $/ \%$ mineral in feed $) \mathrm{x} 100]$.

\section{Ussing Chamber Technique}

Modified Ussing chamber technique as described by Sidler-Lauff et al. (2010) with four different buffer solutions were used: one for each side (serosal or mucosal) of rumen and intestine. For buffer solutions see Wilkens et al. (2011).

An automatic voltage clamping device (Aachen Microclamp, AC Copy Datentechnik, Aachen, Germany) was used to continuously short-circuit the epithelium with correction for the solution 
resistance. The tissue conductance (Gt) was calculated according to Ohm's law after applying bipolar current pulses $( \pm 100 \mathrm{~mA})$ and recording the resulting voltage across the tissue. The values for Gt and the continuously applied short circuit current (Isc) were recorded. Ten minutes after fixation of the tissues in the chambers, $70 \mathrm{kBq}$ was added as ${ }^{45} \mathrm{CaCl}_{2}$ (specific activity 687.82 MBq/mg; PerkinElmer Life Sciences, Rodgau-Jürgensheim, Germany) on the mucosal (resp. serosal) side to measure Ca fluxes from mucosal to serosal (resp. serosal to mucosal) side of the intestinal wall. After an additional $60 \mathrm{~min}$ to allow isotope flux rates to reach a steady state and Isc to stabilize, unidirectional ion flux rates were determined in sequential 20-min periods (Sidler-Lauff et al., 2010). From the mean of determined unidirectional Ca fluxes (Jms, fluxes from the mucosal to the serosal side; Jsm, fluxes from the serosal to the mucosal side), net flux of calcium was calculated by: Jnet $=\mathbf{J m s}-\mathrm{Jsm}(\mathrm{nmol} / \mathrm{h}$ per $\left.\mathrm{cm}^{2}\right)$.

\section{Analysis of Bone Samples}

Before starting (day-14), when the sheep were completely switched to the experimental diet (day0) and at the end of the experiment (day22, post mortem) the left metatarsus of every sheep was scanned in the diaphysis (50\% of the metatarsus length) and in the distal metaphysis (10\% of the metatarsus length) by using peripheral quantitative computed tomography (pQCT; XCT 960 A bone scanner; Stratec Medizinaltechnik, Pforzheim, Germany) as described by Liesegang and Risteli (2005).

The total and cortical bone mineral density (BMD) as well as cortical bone thickness (CBT) were determined in the diaphysis (cortical mode 2, threshold for cortical bone $>640 \mathrm{mg} / \mathrm{cm}^{3}$ ) and trabecular and total BMD in the distal metaphysis (peel mode 2, threshold for trabecular bone $>710 \mathrm{mg} / \mathrm{cm}^{3}$ ). Bone turnover $(\mathbf{B T})$ was estimated by: BT $=$ SCL/OC*1000 (Liesegang et al., 2000). 


\section{RNA Isolation and Quantitative RT-PCR}

Isolation of total RNA of the renal cortex was performed using the RNeasy Plus Mini Kit (Qiagen, Hilden, Germany) according to the manufacturer's instructions. RNA integrity and quality (RNA IQ) of all isolated RNA was checked by using a Qubit 4 fluorometer and a Qubit RNA IQ assay kit (cat. no. Q33222, Thermo Fisher Scientific, Wilmington, DE, USA) in accordance with the manufacturer's protocol. The RNA concentrations were measured by UV spectrophotometry (Thermo Fisher Scientific NanoDrop ${ }^{\mathrm{TM}}$ Spectrophotometer; NanoDrop Technologies, Wilmington, DE, USA). $1 \mu \mathrm{g}$ of isolated RNA was reverse transcribed for qPCR by use of QuantiTect Reverse Transcription Kit (Qiagen, Hilden, Germany) in accordance with the manufacturer`s protocol.

To quantify abundance of the calcium-sensing receptor (CaSR), the apical calcium channel transient receptor potential cation channel subfamily V member 5 (TRPV5), the cytosolic Ca binding protein calbindin D28k (CaBPD28k), the basolateral sodium/Ca exchanger 1 (NCX1), and the reference genes GAPDH (glyceraldehyde-3-phosphate dehydrogenase) and $\boldsymbol{\beta}$-actin, gene specific hydrolysis primers and probes were synthesized by TIB MOLBIOL (Berlin, Germany; Table 2). Reaction mixtures (20 $\mu$ leach) included TaqMan Fast Universal PCR Master Mix (Applied Biosystems, Darmstadt, Germany), 25 ng reverse transcribed RNA, 0.3 $\mu \mathrm{M}$ specific primers and $0.1 \mu \mathrm{M}$ of specific probe. Polymerase chain reaction products were amplified $\left(95^{\circ} \mathrm{C}, 20 \mathrm{~s} ; 95^{\circ} \mathrm{C} ; 45\right.$ cycles of $95^{\circ} \mathrm{C}, 3 \mathrm{~s}$ and $\left.60^{\circ} \mathrm{C}, 30 \mathrm{~s}\right)$ and analyzed on a real-time PCR cycler (CFX96TM, Bio-Rad, Munich, Germany). 
Table 2. Primers and probes used for hydrolysis assays

\begin{tabular}{|c|c|c|c|c|}
\hline Gene $^{1}$ & $\begin{array}{l}\text { Accession } \\
\text { no. }\end{array}$ & $\begin{array}{l}\text { Hybridisation } \\
\text { position }\end{array}$ & $\begin{array}{l}\text { Sense and antisense primers, probes }\left(5^{\prime} \rightarrow\right. \\
\left.3^{\prime}\right)\end{array}$ & Source \\
\hline GAPDH & $\begin{array}{l}\text { NM_0011 } \\
90390.1\end{array}$ & $\begin{array}{l}516-537 \\
594-610 \\
564-586\end{array}$ & $\begin{array}{l}\text { CAAGGTCATCCATGACCACTTT } \\
\text { CGGAAGGGCCATCCACA } \\
\text { FAM- } \\
\text { TGTCCACGCCATCACTGCCACCC- } \\
\text { TMR }\end{array}$ & $\begin{array}{l}\text { (Wilke } \\
\text { ns et al., } \\
\text { 2009) }\end{array}$ \\
\hline$\beta$-actin & $\begin{array}{l}\text { NM_0010 } \\
09784.3\end{array}$ & $\begin{array}{l}259-279 \\
348-369 \\
287-308\end{array}$ & $\begin{array}{l}\text { CTCAGAGCAAGAGAGGCATCC } \\
\text { GCAGCTCGTTGTAGAAGGTGTG } \\
\text { FAM- } \\
\text { CAAGTACCCCATTGAGCACGGC-TMR }\end{array}$ & $\begin{array}{l}\text { (Elfers } \\
\text { et al., } \\
2014)\end{array}$ \\
\hline $\mathrm{CaBP}_{\mathrm{D} 28 \mathrm{k}}$ & $\begin{array}{l}\text { XM_0040 } \\
11846.3\end{array}$ & $\begin{array}{l}397-420 \\
452-477 \\
422-450\end{array}$ & $\begin{array}{l}\text { GTGGATCAGTATGGGCAGAGAGAT } \\
\text { GAAGTTCTCTTCTGTGGGTAACACAT } \\
\text { FAM- } \\
\text { AGCCAACTCTACAATTCCTATTTTTCC } \\
\text { AT-TMR }\end{array}$ & $\begin{array}{l}\text { (Herm } \\
\text { et al., } \\
2015)\end{array}$ \\
\hline CaSR & $\begin{array}{l}\text { XM_0279 } \\
56314.1 \\
\text { and } \\
\text { XM_0279 } \\
56319.1\end{array}$ & $\begin{array}{l}2243-2262 \\
2216-2235 \\
2506-2526 \\
2479-2499 \\
2352-2378 \\
2325-2351\end{array}$ & $\begin{array}{l}\text { GGACTTGAAGGCGAAGAAGAA } \\
\text { FAM- } \\
\text { TGTCATCTGTGCCATTTGGCTCAACA } \\
\text { C-TMR }\end{array}$ & $\begin{array}{l}\text { (Elfers } \\
\text { et al., } \\
2014)\end{array}$ \\
\hline NCX1 & $\begin{array}{l}\text { XM_0121 } \\
73106.3 \\
\text { to } \\
\text { XM_0279 } \\
66903.1\end{array}$ & $\begin{array}{l}2630-2649 \\
2479-2498 \\
2511-2530 \\
2508-2527 \\
2476-2495 \\
2481-2500 \\
2546-2565 \\
2520-2539 \\
2744-2763 \\
2593-2612 \\
2625-2644 \\
2622-2641 \\
2590-2609 \\
2595-2614 \\
2660-2679 \\
2634-2653 \\
2654-2680 \\
2503-2529 \\
2535-2561 \\
2532-2558 \\
2500-2526 \\
2505-2531\end{array}$ & $\begin{array}{l}\text { FAM- } \\
\text { ACGTGATGCACTTTCTGACTGTGTTCT } \\
\text {-BBQ }\end{array}$ & $\begin{array}{l}\text { (Wilke } \\
\text { ns et al., } \\
\text { 2011) }\end{array}$ \\
\hline
\end{tabular}


TRPV5 XM_0279 $1967-1986$ $69122.1 \quad 2051-2067$

AGGAGGAAGGACAAGGGCAT

(Wilke

$2006-2027$

GGACAGGGAAGGGGTCG

ns et al.,

FAM-CGGTGACTGAAAGCGGGCTTCT- 2011) BBQ

${ }^{1}$ GAPDH, glyceraldehyde 3-phosphate dehydrogenase; CaBP $28 \mathrm{k}$, calbindin-D28K; CaSR, Calcium-sensing receptor; NCX1, sodium/Ca exchanger type 1; TRPV5, transient receptor potential vanilloid type 5 .

Abundance of parathyroid hormone receptor (PTHR), 1 $\alpha$-OHase (CYP27B1), 24-OHase (CYP24A1) and reference gene ribosomal protein S9 (RPS9) were analyzed by SYBR Green PCR assays using the SensiFAST ${ }^{\mathrm{TM}}$ SYBR ${ }^{\circledR}$ No-ROX Kit (Bioline, London, UK). Gene specific primers were purchased by TIB MOLBIOL (Berlin, Germany; Table 3). Reaction mixtures (20 $\mu \mathrm{l}$ each) contained SensiFast Mastermix (Bioline, London, UK), 25 ng reverse transcribed RNA and $0.2 \mu \mathrm{M}$ specific primers. The PCR products were amplified using the realtime PCR cycler mentioned above, but another program $\left(95^{\circ} \mathrm{C}, 3 \mathrm{~min} ; 40\right.$ cycles of $95^{\circ} \mathrm{C}, 10 \mathrm{~s}$ and $60^{\circ} \mathrm{C}, 30 \mathrm{~s}$ ). The thermal profile for determining the melting curve began with an incubation of $10 \mathrm{~min}$ at $55^{\circ} \mathrm{C}$ with a gradual increase in temperature $\left(0.5^{\circ} \mathrm{C} / 10 \mathrm{~s}\right)$. 
Table 3. Primers used for SYBR Green assays

\begin{tabular}{|c|c|c|c|c|}
\hline Gene $^{1}$ & Accession no. & $\begin{array}{l}\text { Hybridisatio } \\
\mathrm{n} \text { position }\end{array}$ & $\begin{array}{l}\text { Sense and antisense primers, } \\
\text { probes }\left(5^{\prime} \rightarrow 3^{\prime}\right)\end{array}$ & $\begin{array}{l}\text { Sourc } \\
\mathrm{e}\end{array}$ \\
\hline RPS9 & $\begin{array}{l}\text { XM_027978858. } \\
1 \text { and } \\
\text { XM_027978859. } \\
1\end{array}$ & $\begin{array}{l}188-208 \\
250-270 \\
231-252 \\
293-314\end{array}$ & $\begin{array}{l}\text { CGCCTCGACCAAGAGCTGAA } \\
\text { G } \\
\text { CTCCAGACCTCACGTTTGTTC } \\
\text { C }\end{array}$ & $\begin{array}{l}\text { (Sacc } \\
\text { o et } \\
\text { al., } \\
\text { 2012) }\end{array}$ \\
\hline $\begin{array}{l}\text { CYP24A } \\
1\end{array}$ & $\begin{array}{l}\text { XM_027976458. } \\
1 \quad \text { and } \\
\text { XM_027976459. } \\
1\end{array}$ & $\begin{array}{l}230-249 \\
457-476 \\
\text { both }\end{array}$ & $\begin{array}{l}\text { GAGGCCTCAAGAAACAGCAC } \\
\text { CTGACCСTCTGCCAGTCTTC }\end{array}$ & $\begin{array}{l}\text { (Herm } \\
\text { et al., } \\
2015)\end{array}$ \\
\hline $\begin{array}{l}\text { CYP27B } \\
1\end{array}$ & $\begin{array}{l}\text { XM_027967507. } \\
1\end{array}$ & $\begin{array}{l}1701-1720 \\
2033-2052\end{array}$ & $\begin{array}{l}\text { ACCTGGAAATTCCCGTGTCC } \\
\text { GATGCTTCTCTCAGGCACCA }\end{array}$ & $\begin{array}{l}\text { (Herm } \\
\text { et al., } \\
2015)\end{array}$ \\
\hline PTHR & $\begin{array}{l}\text { XM_027957724. } \\
1 \text { to } \\
\text { XM_027957728. } \\
1\end{array}$ & $\begin{array}{l}1416-1435 \\
1377-1396 \\
2060-2079 \\
1076-1095 \\
1245-1264 \\
1666-1685 \\
1627-1646 \\
2310-2329 \\
1326-1345 \\
1495-1514\end{array}$ & AGCCTGTACCTCACCATTGC & $\begin{array}{l}\text { (Herm } \\
\text { et al., } \\
2015)\end{array}$ \\
\hline
\end{tabular}

${ }^{1}$ RPS9, ribosomal protein S9; CYP24A1, 24-hydroxylase; CYP27B1, $1 \alpha$-hydroxylase; PTHR, parathyroid hormone receptor.

Absolute copy numbers were determined using calibration curves generated with cloned PCR fragment standards (Wilkens et al., 2009). The expression stability of the reference genes was tested using RefFinder (Xie et al., 2012). Abundance of genes of interest was normalized to a mean of three reference genes: GAPDH, $\beta$-actin and RPS9. Reactions were performed in duplicate and included cDNA samples, genomic standards and a no-template control with water. Analysis of renal vitamin D receptor (VDR) and apical calcium channel transient receptor potential cation channel subfamily $\mathrm{V}$ member 5 and 6 (TRPV5/6) mRNA abundance was performed differently. The differences are as follows: RNA was extracted by using TRI Reagent protocol (TRI Reagent Solution, Ambion, Rotkreuz, Switzerland). Primers and probes were synthetized by Mircosynth AG (Balgach, Switzerland; Table 4). The reaction mixture (20 $\mu 1$ 
each) included Promega GoTaq Probe qPCR Master Mix (Promega, Madison, USA), 10 ng reverse transcribed RNA, $0.6 \mu \mathrm{M}$ specific primers and $0.25 \mu \mathrm{M}$ of specific probe. Polymerase chain reaction products were amplified $\left(95^{\circ} \mathrm{C}, 2 \mathrm{~min} ; 45\right.$ cycles of $95^{\circ} \mathrm{C}, 15 \mathrm{~s}$ and $\left.60^{\circ} \mathrm{C}, 60 \mathrm{~s}\right)$ and analyzed on ABI 7500 Fast real-time PCR System (Applied Biosystems, Darmstadt, Germany).

Table 4. Primers and probes used for VDR and TRPV5/6 (hydrolysis assays)

\begin{tabular}{|c|c|c|c|c|}
\hline Gene $^{1}$ & Accession no. & $\begin{array}{l}\text { Hybridisatio } \\
\mathrm{n} \text { position }\end{array}$ & $\begin{array}{l}\text { Sense and antisense primers, probes } \\
\left(5^{\prime} \rightarrow 3^{\prime}\right)\end{array}$ & Source \\
\hline GAPD & NM_00119039 & $85-104$ & GTCACCAGGGCTGCTTTTAA & (Neme \\
\hline $\mathrm{H}$ & $0.1^{-}+1-10$ & $\begin{array}{l}257-276 \\
196-215\end{array}$ & $\begin{array}{l}\text { ATCTCGCTCCTGGAAGATGG } \\
\text { FAM- } \\
\text { AAGTTCCACGGCACAGTCAA- } \\
\text { BHQ-1 }\end{array}$ & $\begin{array}{l}\text { th et } \\
\text { al., } \\
\text { 2017) }\end{array}$ \\
\hline$\beta$-actin & $\begin{array}{l}\text { NM_00100978 } \\
4.3\end{array}$ & $\begin{array}{l}319-338 \\
426-445 \\
350-369\end{array}$ & $\begin{array}{l}\text { ACTGGGACGACATGGAGAAG } \\
\text { GTCATCTTCTCACGGTTGGC } \\
\text { FAM- } \\
\text { CACCTTCTACAACGAGCTGC- } \\
\text { BHQ-1 }\end{array}$ & $\begin{array}{l}\text { (Neme } \\
\text { th et } \\
\text { al., } \\
\text { 2017) }\end{array}$ \\
\hline RPS9 & $\begin{array}{l}\text { XM_02797885 } \\
8.1 \\
\text { and } \\
\text { XM_02797885 } \\
9.1\end{array}$ & $\begin{array}{l}516-534 \\
591-608 \\
561-587 \text { and } \\
578-596 \\
653-670 \\
623-649\end{array}$ & $\begin{array}{l}\text { GTCACATCAGGGTCCGCAA } \\
\text { GGGAGCGCAGGGAGAAGT } \\
\text { FAM- } \\
\text { TCGTGCGCCTGGACTCCCAGAA } \\
\text { GCACA-BHQ-1 }\end{array}$ & $\begin{array}{l}\text { This } \\
\text { study }\end{array}$ \\
\hline VDR & $\begin{array}{l}\text { XM_02796740 } \\
3.1\end{array}$ & $\begin{array}{l}1101-1120 \\
1260-1279 \\
1172-1191\end{array}$ & $\begin{array}{l}\text { CAGATCGTGCTGCTGAAGTC } \\
\text { ACCTGGAACTTGATGAGGGG } \\
\text { FAM- } \\
\text { CGACATGTCCTGGACCTGTG- } \\
\text { BHQ-1 }\end{array}$ & $\begin{array}{l}\text { (Neme } \\
\text { th et } \\
\text { al., } \\
\text { 2017) }\end{array}$ \\
\hline $\begin{array}{l}\text { TRPV5 } \\
/ 6\end{array}$ & $\begin{array}{l}\text { XM_02796912 } \\
2.1 \text { and } \\
\text { XM_00400812 } \\
9.4\end{array}$ & $\begin{array}{l}608-625 \\
730-747 \\
638-658 \\
\text { both }\end{array}$ & $\begin{array}{l}\text { TCGTCCTCCAGCCCAACA } \\
\text { CACTCCGGCCAGCTTGAA } \\
\text { FAM- } \\
\text { GCCAGATGTACAACCTGCTGC- } \\
\text { BHQ-1 }\end{array}$ & $\begin{array}{l}\text { This } \\
\text { study }\end{array}$ \\
\hline
\end{tabular}

${ }^{1}$ GAPDH, glyceraldehyde 3-phosphate dehydrogenase; VDR, vitamin D receptor; RPS9, ribosomal protein S9; VDR, vitamin D receptor; TRPV5/6, transient receptor potential vanilloid type 5 and 6 . 
The used primers derived either from ovine, caprine or bovine sequences. Efficiency of all primers included in this study was tested using dilution series. Amplification products were sequenced (GATC biotech AG, Konstanz, Germany resp. Microsynth AG, Balgach, Switzerland) and sequence specificity of amplicons was verified by NCBI Blast database (https://blast.ncbi.nlm.nih.gov/Blast.cgi).

\section{Statistical Analysis}

All statistical analyses were conducted with Excel (Microsoft Excel Professional Plus 2016, Microsoft Corporation, Redmond, WA, USA) and the statistical software R version 4.0.2 (R: A Language and Environment for Statistical Computing. R Foundation for Statistical Computing. Vienna, Austria. URL: www.R-project.org) using a generalized linear mixed model using Template Model Builder (glmmTMB) for all analyses with repeated measurements and a linear or general linear model $(\mathrm{lm} / \mathrm{glm})$ for measurements without repetitions. When the data were not normally distributed, a gamma (log) regression model was used as this gave the best fit compared to a linear model or a lognormal/gaussian glm/glmmTMB by maximum likelihood. The association of the outcomes on various factors was tested with multiple independent variables. The independent variables were DCAD (categorical variable, high or low), Ca (categorical variable, normal or low) and day (categorical variable, day-14, day0, day4, day7, day14, day22; continuous variable of the $P$ values for "day" reported in the tables). In the models, day was analyzed as a factor, excluding the $P$ values for day reported in the tables (see section tables) which were obtained by treating day as a numeric variable. HighDCAD, and nCa were releveled as the references and day-14 as the baseline of the experiment. When there were repeated measurements, sheep and group were used as grouping variables or random effects. The nested random effect of sheep within group was denoted by (1|Group/Sheep) and deals with any differences between both sheep and group at baseline (day-14). Independent variables were tested for multiple comparisons (including interactions between the independent variables). To remove non-significant variables in the model, backward selection was used for 
all regression models until the model with the lowest BIC remained. Parameters with a $P<0.05$ (i.e., the probability of the null hypothesis of no association between the variables) in the final model were considered significant. All data are reported as means \pm standard error (SE). Nonsignificant variables of the models are not reported.

\section{RESULTS}

\section{Bodyweight and BCS}

Due to normal growth, the body weight of all groups increased from $49.6 \pm 4.45 \mathrm{~kg}$ before starting the experiment up to $57.0 \pm 4.41 \mathrm{~kg}$ at the end of the experiment (mean daily weight gain of $0.2 \pm 0.02 \mathrm{~kg}$ ). The range of BCS was $2.59 \pm 0.21$ before starting the experiment and $2.68 \pm 0.14$ at the end of the experiment. Between groups, no significant differences in body weight and BCS were found at any point in time.

\section{$p Q C T$}

Bone parameters analyzed by pQCT, changed due to the normal growth of the young sheep, but did not differ significantly between groups at any point in time: Total BMD in the diaphysis showed no significant changes over time in all groups. It was from $821.26 \pm 45.39$ before the start of the experiment and $841.03 \pm 50.57 \mathrm{mg} / \mathrm{cm}^{3}$ at the end of the experiment $(P=0.07)$. Cortical BMD in the diaphysis increased from $1081.20 \pm 30.57$ to $1112.31 \pm 18.95 \mathrm{mg} / \mathrm{cm}^{3}(P$ $=0.003)$. CBT in the diaphysis slightly decreased from $4.00 \pm 0.32$ to $3.92 \pm 0.29 \mathrm{mg} / \mathrm{cm}^{3}(P=$

0.05). Trabecular BMD in the metaphysis increased from $383.82 \pm 44.91$ to $438.47 \pm 32.66$ $\mathrm{mg} / \mathrm{cm}^{3}(P<0.001)$. Total BMD in the metaphysis increased from $443.59 \pm 41.56$ to $502.25 \pm$ $29.50 \mathrm{mg} / \mathrm{cm}^{3}(P<0.001)$.

\section{Blood and Serum Parameters}

Blood and serum parameters significantly associated with the different diets are listed in Table 5. LowDCAD showed a slight tendency to be associated with a decrease in blood $\mathrm{pH}(P=$ 0.103). Furthermore, lowDCAD was significantly associated with higher iCa in blood and 
higher serum Ca concentrations $(P=0.046$ and $P=0.002$ resp.). Serum Ca concentrations showed an overall decrease over the entire observation period (between day-14 and day22; $P<$ 0.001). Serum PHOS concentrations were not associated with the different diets.

LowCa was associated with significantly higher serum SCL concentrations $(P<0.001)$. SCL concentrations in serum were higher on all days compared to day-14, but did not change throughout the trial. LowDCAD was associated with lower serum OC concentrations $(P<$ 0.001), but only days 14 and 22 differed significantly from day-14. Increased bone turnover (SCL: OC*1000) was associated with both dietary factors $(P<0.001$ both), and was higher on all days compared to day-14, but did not differ significantly throughout the trial. It is important to note that bone turnover rates indicated different starting points at baseline. However, the nested mixed model was appropriate to deal with this. Serum 25vitD concentration was not associated with the different diets, but with time. On day0, serum 25vitD concentrations were significantly higher compared to day-14. During the trial, 25vitD dropped and reached significant lower values on day22 compared to day-14. In contrast, lowCa was associated with increased 1,25 vitD serum levels $(P<0.001) .1,25$ vitD was increased on all days compared to day-14, but did not change throughout the trial. 
Table 5. Blood and serum parameters of sheep fed either high or low Dietary cation-anion difference diets (highDCAD/lowDCAD) combined with normal or low calcium supply (nCa/lowCa). For statistical analysis, a glmmTMB gaussian resp. gamma(log) family model was used with day as a categorical variable, excluding the $P$ values for day reported in the tables which were obtained by treating day as a numeric variable. For $\mathrm{pH}$ and ionized calcium in blood, a lm model was used instead of glmmTMB as these variables were measured only on one day (day of sacrifice)

\begin{tabular}{|c|c|c|c|c|c|c|}
\hline \multirow[b]{2}{*}{ Dependent variable } & \multicolumn{4}{|c|}{ Group (means \pm SE) } & \multirow[b]{2}{*}{$\begin{array}{l}\text { Independent } \\
\text { variable }\end{array}$} & \multirow[b]{2}{*}{$P$-value } \\
\hline & $\begin{array}{l}\text { highDCAD } \\
\text { nCa }\end{array}$ & $\begin{array}{l}\text { highDCAD } \\
\text { lowCa }\end{array}$ & $\begin{array}{l}\text { lowDCAD } \\
\text { nCa }\end{array}$ & $\begin{array}{l}\text { lowDCAD } \\
\text { lowCa }\end{array}$ & & \\
\hline $\begin{array}{l}\text { Blood pH } \\
\text { day22 }\end{array}$ & $7.39 \pm 0.02$ & $7.34 \pm 0.07$ & $7.30 \pm 0.06$ & $7.33 \pm 0.05$ & n.s..$^{5}$ & \\
\hline $\begin{array}{l}\mathrm{iCa}^{1}, \mathrm{mmol} / \mathrm{L} \\
\quad \text { day } 22\end{array}$ & $1.18 \pm 0.04$ & $1.15 \pm 0.09$ & $1.23 \pm 0.07$ & $1.23 \pm 0.10$ & lowDCAD ${ }^{6}$ & 0.046 \\
\hline \multicolumn{7}{|l|}{ Calcium, mmol/L } \\
\hline day-14 & $2.52 \pm 0.20$ & $2.49 \pm 0.10$ & $2.59 \pm 0.15$ & $2.55 \pm 0.15$ & lowDCAD & 0.002 \\
\hline day0 & $2.43 \pm 0.07$ & $2.32 \pm 0.10$ & $2.53 \pm 0.20$ & $2.50 \pm 0.11$ & day $^{8}$ & $<0.001$ \\
\hline day4 & $2.47 \pm 0.07$ & $2.29 \pm 0.07$ & $2.45 \pm 0.19$ & $2.43 \pm 0.13$ & & \\
\hline day7 & $2.39 \pm 0.11$ & $2.34 \pm 0.14$ & $2.46 \pm 0.14$ & $2.40 \pm 0.17$ & & \\
\hline day14 & $2.31 \pm 0.08$ & $2.27 \pm 0.07$ & $2.45 \pm 0.17$ & $2.47 \pm 0.14$ & & \\
\hline day22 & $2.35 \pm 0.14$ & $2.23 \pm 0.09$ & $2.54 \pm 0.23$ & $2.37 \pm 0.10$ & & \\
\hline \multicolumn{7}{|l|}{ Phosphate, $\mathrm{mmol} / \mathrm{L}$} \\
\hline day-14 & $2.01 \pm 0.22$ & $1.98 \pm 0.19$ & $1.98 \pm 0.22$ & $1.93 \pm 0.23$ & n.s. & \\
\hline day0 & $1.90 \pm 0.20$ & $2.12 \pm 0.53$ & $1.74 \pm 0.16$ & $1.72 \pm 0.30$ & & \\
\hline day4 & $1.87 \pm 0.45$ & $2.06 \pm 0.40$ & $1.74 \pm 0.25$ & $2.05 \pm 0.57$ & & \\
\hline day7 & $2.01 \pm 0.16$ & $2.03 \pm 0.45$ & $1.65 \pm 0.44$ & $1.80 \pm 0.48$ & & \\
\hline day14 & $2.13 \pm 0.30$ & $2.06 \pm 0.39$ & $1.82 \pm 0.42$ & $1.81 \pm 0.38$ & & \\
\hline day22 & $2.18 \pm 0.21$ & $2.08 \pm 0.58$ & $1.69 \pm 0.35$ & $1.77 \pm 0.49$ & & \\
\hline $\begin{array}{l}\text { Serum Crosslaps, } \\
\mathrm{ng} / \mathrm{mL}\end{array}$ & & & & & & \\
\hline
\end{tabular}




\begin{tabular}{|c|c|c|c|c|c|c|}
\hline day-14 & $1.33 \pm 0.25$ & $1.60 \pm 0.40$ & $1.56 \pm 0.32$ & $1.75 \pm 0.54$ & \multirow{6}{*}{$\begin{array}{l}\text { lowCa } \\
\text { day }\end{array}$} & $<0.001$ \\
\hline day0 & $1.51 \pm 0.28$ & $2.17 \pm 0.60$ & $1.64 \pm 0.25$ & $2.16 \pm 0.47$ & & \multirow[t]{5}{*}{0.008} \\
\hline day4 & $1.49 \pm 0.25$ & $2.21 \pm 0.45$ & $1.63 \pm 0.37$ & $1.97 \pm 0.31$ & & \\
\hline day7 & $1.50 \pm 0.39$ & $2.32 \pm 0.49$ & $1.76 \pm 0.08$ & $2.10 \pm 0.50$ & & \\
\hline day 14 & $1.25 \pm 0.30$ & $2.12 \pm 0.79$ & $1.68 \pm 0.42$ & $2.11 \pm 0.27$ & & \\
\hline day 22 & $1.34 \pm 0.33$ & $1.91 \pm 0.45$ & $1.82 \pm 0.21$ & $2.32 \pm 0.29$ & & \\
\hline \multicolumn{7}{|c|}{$\begin{array}{l}\text { Osteocalcin, } \\
\mathrm{ng} / \mathrm{mL}\end{array}$} \\
\hline day-14 & $152.5 \pm 23.2$ & $152.1 \pm 19.5$ & $154.7 \pm 9.9$ & $148.8 \pm 12.2$ & \multirow{6}{*}{$\begin{array}{l}\text { lowDCAD } \\
\text { day }\end{array}$} & \multirow{6}{*}{$\begin{array}{l}<0.001 \\
0.005\end{array}$} \\
\hline day0 & $156.4 \pm 7.0$ & $164.8 \pm 13.9$ & $134.4 \pm 24.7$ & $134.8 \pm 16.1$ & & \\
\hline day4 & $155.8 \pm 6.5$ & $160.9 \pm 13.2$ & $132.5 \pm 19.0$ & $139.8 \pm 18.7$ & & \\
\hline day7 & $165.2 \pm 13.3$ & $159.9 \pm 14.0$ & $145.2 \pm 32.0$ & $138.3 \pm 20.4$ & & \\
\hline day 14 & $149.1 \pm 30.9$ & $159.4 \pm 15.2$ & $132.3 \pm 26.1$ & $125.9 \pm 15.3$ & & \\
\hline day22 & $144.8 \pm 17.7$ & $159.9 \pm 19.0$ & $122.2 \pm 17.1$ & $134.4 \pm 14.9$ & & \\
\hline \multicolumn{7}{|c|}{ 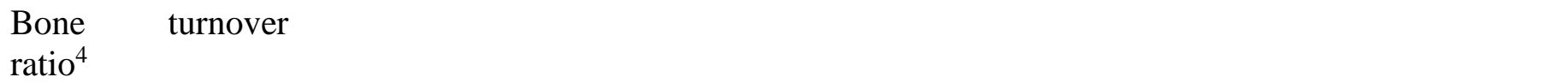 } \\
\hline day-14 & $8.83 \pm 1.85$ & $10.70 \pm 3.00$ & $10.09 \pm 2.03$ & $11.84 \pm 3.89$ & \multirow{6}{*}{$\begin{array}{l}\text { lowDCAD } \\
\text { lowCa } \\
\text { day }\end{array}$} & $<0.001$ \\
\hline day0 & $9.59 \pm 1.48$ & $13.10 \pm 3.23$ & $12.41 \pm 2.33$ & $16.02 \pm 2.52$ & & $<0.001$ \\
\hline day4 & $9.59 \pm 1.53$ & $13.69 \pm 2.41$ & $12.45 \pm 3.18$ & $14.09 \pm 1.01$ & & $<0.001$ \\
\hline day7 & $9.02 \pm 1.98$ & $14.53 \pm 2.72$ & $12.58 \pm 2.76$ & $15.27 \pm 3.53$ & & \\
\hline day 14 & $8.62 \pm 2.26$ & $13.44 \pm 5.12$ & $12.76 \pm 2.60$ & $16.85 \pm 2.44$ & & \\
\hline day 22 & $9.35 \pm 2.55$ & $11.93 \pm 2.44$ & $15.15 \pm 2.88$ & $17.32 \pm 1.70$ & & \\
\hline \multicolumn{7}{|c|}{$25 \mathrm{vitD}^{2}, \mathrm{nmol} / \mathrm{L}$} \\
\hline day-14 & $135.1 \pm 20.2$ & $125.3 \pm 9.9$ & $134.2 \pm 16.2$ & $138.1 \pm 21.6$ & \multirow[t]{6}{*}{ day } & \multirow[t]{6}{*}{0.001} \\
\hline day0 & $170.5 \pm 29.4$ & $137.7 \pm 14.7$ & $149.7 \pm 19.4$ & $143.3 \pm 18.5$ & & \\
\hline day4 & $180.2 \pm 22.5$ & $136.8 \pm 11.8$ & $145.5 \pm 16.8$ & $135.8 \pm 26.8$ & & \\
\hline day7 & $169.4 \pm 13.6$ & $131.0 \pm 13.7$ & $132.9 \pm 13.9$ & $137.9 \pm 25.1$ & & \\
\hline day 14 & $156.7 \pm 13.8$ & $127.6 \pm 9.6$ & $127.7 \pm 12.9$ & $128.1 \pm 18.4$ & & \\
\hline day22 & $148.2 \pm 19.8$ & $120.2 \pm 13.1$ & $117.4 \pm 14.1$ & $117.7 \pm 22.3$ & & \\
\hline
\end{tabular}




$\begin{array}{lllllll}\text { day-14 } & 70.97 \pm 14.68 & 68.02 \pm 12.85 & 61.22 \pm 16.48 & 69.10 \pm 10.39 & \text { lowCa } & <0.001 \\ \text { day0 } & 62.37 \pm 24.78 & 125.67 \pm 37.6 & 62.52 \pm 20.26 & 147.05 \pm 53.0 & \text { day } & <0.001 \\ \text { day4 } & 61.59 \pm 19.60 & 140.21 \pm 15.6 & 63.50 \pm 16.03 & 158.53 \pm 71.7 & & \\ \text { day7 } & 62.18 \pm 24.44 & 118.67 \pm 40.4 & 55.32 \pm 17.65 & 176.87 \pm 77.2 & & \\ \text { day14 } & 71.61 \pm 18.61 & 128.02 \pm 18.1 & 70.38 \pm 21.54 & 172.58 \pm 81.4 & \\ \text { day22 } & 69.32 \pm 24.71 & 120.89 \pm 21.2 & 57.87 \pm 7.51 & 185.05 \pm 55.1 & \end{array}$

${ }_{1} \mathrm{iCa}$, ionized $\mathrm{Ca} ;{ }^{2} 25 \mathrm{vitD}, 25$-Hydroxy Vitamin $\mathrm{D} ;{ }^{3} 1,25 \mathrm{vitD}, 1,25$-dihydroxyvitamin $\mathrm{D} ;{ }^{4}$ bone turnover, calculated as Serum Crosslaps: Osteocalcin*1000; ${ }^{5}$ n.s., not significant $(\mathrm{P}>0.05) ;{ }^{6}$ compared to highDCAD; ${ }^{7}$ compared to $\mathrm{nCa} ;{ }^{8} \mathrm{day}$ as a numeric variable 


\section{Urine Parameters}

Significant urine parameters of the sheep as associated with the different diets are displayed in Table 6. LowDCAD was associated with lower urine $\mathrm{pH}$ and higher FE of $\mathrm{Ca}(P<0.001$ both). LowCa was also associated with higher FE of $\mathrm{Ca}$, albeit less so than DCAD $(P<0.001)$. LowDCAD and lowCa in interaction slightened the associated increase of each dietary factor on FE of Ca. Urine $\mathrm{pH}$ was lower on all days compared to day-14 and decreased during the trial. FE of Ca was higher on all days compared to day-14 and did not change throughout the trial. FE of PHOS was not associated with the different diets, but with time. FE of PHOS was higher on all days compared to day-14 and increased throughout the trial $(P<0.001)$. 
Table 6. Urine parameters as well as fractional excretion (FE) of calcium and phosphate in sheep fed either high or low Dietary cation-anion difference diets (highDCAD/lowDCAD) combined with normal or low Ca supply (nCa/lowCa). For statistical analysis, a glmmTMB gaussian resp. gamma(log) family model was used with day as a categorical variable, excluding the $P$ values for day reported in the tables which were obtained by treating day as a numeric variable

\begin{tabular}{|c|c|c|c|c|c|c|}
\hline \multirow[b]{2}{*}{ Dependent variable } & \multicolumn{4}{|c|}{ Group (means \pm SE) } & \multirow[b]{2}{*}{$\begin{array}{l}\text { Independent } \\
\text { variable }\end{array}$} & \multirow[b]{2}{*}{$P$-value } \\
\hline & $\begin{array}{l}\text { highDCAD } \\
\mathrm{nCa}\end{array}$ & $\begin{array}{l}\text { highDCAD } \\
\text { lowCa }\end{array}$ & $\begin{array}{l}\text { lowDCAD } \\
\mathrm{nCa}\end{array}$ & $\begin{array}{l}\text { lowDCAD } \\
\text { lowCa }\end{array}$ & & \\
\hline \multicolumn{7}{|l|}{ Urine $\mathrm{pH}$} \\
\hline day-14 & $8.72 \pm 0.16$ & $8.73 \pm 0.23$ & $8.64 \pm 0.08$ & $8.65 \pm 0.09$ & lowDCAD ${ }^{2}$ & $<0.001$ \\
\hline day0 & $8.61 \pm 0.15$ & $8.32 \pm 0.4$ & $6.84 \pm 1.51$ & $7.09 \pm 1.59$ & day $^{4}$ & $<0.001$ \\
\hline day4 & $8.54 \pm 0.15$ & $7.78 \pm 1.37$ & $6.71 \pm 1.43$ & $5.84 \pm 0.93$ & & \\
\hline day7 & $8.57 \pm 0.25$ & $7.27 \pm 1.47$ & $6.05 \pm 1.41$ & $6.16 \pm 1.55$ & & \\
\hline day 14 & $8.53 \pm 0.08$ & $7.83 \pm 1.12$ & $6.13 \pm 1.53$ & $5.61 \pm 0.53$ & & \\
\hline day22 & $8.62 \pm 0.10$ & $8.41 \pm 0.09$ & $5.51 \pm 0.82$ & $5.61 \pm 0.53$ & & \\
\hline \multicolumn{7}{|l|}{$\mathrm{FE}^{1}$ Calcium, $\%$} \\
\hline day-14 & $0.08 \pm 0.04$ & $0.36 \pm 0.35$ & $0.35 \pm 0.20$ & $0.29 \pm 0.10$ & lowDCAD & $<0.001$ \\
\hline day0 & $0.07 \pm 0.04$ & $0.27 \pm 0.20$ & $2.92 \pm 3.40$ & $1.53 \pm 1.45$ & low $\mathrm{Ca}^{3}$ & $<0.001$ \\
\hline day4 & $0.06 \pm 0.03$ & $0.55 \pm 0.97$ & $1.81 \pm 1.51$ & $1.96 \pm 1.59$ & lowDCAD*lowCa & $<0.001$ \\
\hline day7 & $0.14 \pm 0.09$ & $0.29 \pm 0.24$ & $3.03 \pm 1.60$ & $2.10 \pm 3.03$ & day & $<0.001$ \\
\hline day14 & $0.07 \pm 0.03$ & $0.32 \pm 0.28$ & $2.85 \pm 1.31$ & $3.09 \pm 2.70$ & & \\
\hline day 22 & $0.11 \pm 0.12$ & $0.17 \pm 0.09$ & $3.79 \pm 2.85$ & $4.01 \pm 4.39$ & & \\
\hline \multicolumn{7}{|l|}{$\mathrm{FE}^{1}$ Phosphate, $\%$} \\
\hline day-14 & $0.39 \pm 0.45$ & $0.49 \pm 0.65$ & $0.23 \pm 0.05$ & $0.34 \pm 0.39$ & day & $<0.001$ \\
\hline day0 & $0.52 \pm 0.81$ & $3.26 \pm 7.45$ & $0.18 \pm 0.04$ & $1.81 \pm 3.75$ & & \\
\hline day4 & $0.88 \pm 1.47$ & $1.93 \pm 2.35$ & $0.21 \pm 0.04$ & $1.70 \pm 3.15$ & & \\
\hline day7 & $0.74 \pm 0.76$ & $1.26 \pm 2.24$ & $0.21 \pm 0.04$ & $1.22 \pm 2.45$ & & \\
\hline
\end{tabular}



day 14
$0.25 \pm 0.25$
$2.00 \pm 3.11$
$0.26 \pm 0.08$
$2.93 \pm 4.91$
day 22
$0.62 \pm 0.89 \quad 1.96 \pm 4.27$
$0.42 \pm 0.43$
$2.42 \pm 3.30$

${ }^{1} \mathrm{FE}$, Fractional Excretion; ${ }^{2}$ compared to highDCAD; ${ }^{3}$ compared to $\mathrm{nCa} ;{ }^{4}$ day as a numeric variable 


\section{Rumen Parameters}

Significant rumen parameters as associated with the different diets are presented in Table 7. Ca mineral concentration analyzed in ruminal fluid on the day of sacrifice was not associated with the different diets. PHOS in ruminal fluid was, compared to a diet high in DCAD and normal in $\mathrm{Ca}$, associated with a lower concentration only when DCAD was high and $\mathrm{Ca}$ was low $(P=$ $0.028)$ 
Table 7. Effect of different diets on the analysed parameters in ruminal fluid, net calcium (Ca) ion fluxes (Jnet) through ruminal and jejunal mucosa and apparent digestibility $(\mathrm{AD})$ of calcium and phosphate (mean \pm SE). Different sheep feeding groups received either a diet high or low in Dietary cation-anion difference (highDCAD/ lowDCAD) combined with normal or low Ca supply (nCa/ lowCa). For statistical analysis, a lm resp. glm gamma(log) family model was used, except for AD where a glmmTMB gaussian family model was used with day as a categorical variable, excluding the $P$ values for day reported in the tables which were obtained by treating day as a numeric variable

\begin{tabular}{|c|c|c|c|c|c|c|}
\hline \multirow[b]{2}{*}{ Dependent variable } & \multicolumn{4}{|c|}{ Group (means \pm SE) } & \multirow[b]{2}{*}{$\begin{array}{l}\text { Independent } \\
\text { variable }\end{array}$} & \multirow[b]{2}{*}{$P$-value } \\
\hline & $\begin{array}{l}\text { highDCAD } \\
\text { nCa }\end{array}$ & $\begin{array}{l}\text { highDCAD } \\
\text { lowCa }\end{array}$ & $\begin{array}{l}\text { lowDCAD } \\
\text { nCa }\end{array}$ & $\begin{array}{l}\text { lowDCAD } \\
\text { lowCa }\end{array}$ & & \\
\hline Rumen fluid & & & & & & \\
\hline Calcium, mmol/L & $1.07 \pm 0.24$ & $1.05 \pm 0.18$ & $1.17 \pm 0.17$ & $1.10 \pm 0.27$ & n.s. ${ }^{2}$ & \\
\hline Phosphate, mmol/L & $25.77 \pm 1.76$ & $21.59 \pm 3.04$ & $24.87 \pm 4.17$ & $27.94 \pm 4.36$ & highDCADlowCa ${ }^{3}$ & 0.028 \\
\hline Ussing Chamber & & & & & & \\
\hline Rumen, $\mathrm{nmol} / \mathrm{h} / \mathrm{cm}^{2}$ & $1331+241$ & & & & & \\
\hline $\begin{array}{l}\text { mucoserosal } \\
\text { seromucosal }\end{array}$ & $\begin{array}{l}13.31 \pm 2.41 \\
1.36 \pm 0.76\end{array}$ & $\begin{array}{l}12.20 \pm 3.72 \\
1.76 \pm 0.46\end{array}$ & $\begin{array}{l}12.87 \pm 1.98 \\
2.26 \pm 1.19\end{array}$ & $\begin{array}{l}14.90 \pm 4.26 \\
4.15 \pm 5.16\end{array}$ & $\begin{array}{l}\text { n.s. } \\
\text { n.s. }\end{array}$ & \\
\hline Jnet $^{1}$ & $11.96 \pm 2.46$ & $10.44 \pm 3.53$ & $10.60 \pm 1.32$ & $10.75 \pm 5.00$ & n.s. & \\
\hline $\begin{array}{l}\text { Jejunum, } \\
\mathrm{nmol} / \mathrm{h} / \mathrm{cm}^{2}\end{array}$ & & & & & & \\
\hline mucoserosal & $28.66 \pm 7.17$ & $33.89 \pm 3.68$ & $32.08 \pm 7.45$ & $32.40 \pm 6.92$ & n.s. & \\
\hline seromucosal & $25.02 \pm 5.71$ & $18.50 \pm 3.84$ & $21.15 \pm 4.52$ & $15.31 \pm 7.90$ & lowCa ${ }^{4}$ & 0.020 \\
\hline Jnet $^{1}$ & $3.64 \pm 2.96$ & $15.39 \pm 6.03$ & $10.93 \pm 5.23$ & $17.09 \pm 5.34$ & $\begin{array}{l}\text { lowDACD } \\
\text { lowCa } \\
\text { lowDCAD*lowCa }\end{array}$ & $\begin{array}{l}0.003 \\
<0.001 \\
0.039\end{array}$ \\
\hline
\end{tabular}

Apparent
digestibility
Calcium, \%




\begin{tabular}{lllllll} 
day0 & $-13.69 \pm 20.50$ & $-8.26 \pm 30.22$ & $6.74 \pm 8.15$ & $-11.83 \pm 12.66$ & lowDCADnCa $^{6}$ & 0.027 \\
day4 & $-17.79 \pm 23.70$ & $-20.19 \pm 23.54$ & $1.51 \pm 11.14$ & $-19.02 \pm 30.96$ & & \\
day7 & $4.9 \pm 11.12$ & $-7.85 \pm 8.89$ & $3.95 \pm 10.27$ & $-11.24 \pm 10.71$ & & \\
day14 & $-16.32 \pm 22.24$ & $-7.13 \pm 46.58$ & $0.32 \pm 23.22$ & $-0.72 \pm 17.42$ & & \\
day22 & $-11.47 \pm 18.16$ & $-36.24 \pm 48.45$ & $25.99 \pm 31.28$ & $-3.83 \pm 6.02$ & & \\
\hline Apparent & & & &
\end{tabular}

Apparent

digestibility

Phosphor, \%

$\begin{array}{llllll}\text { day0 } & -25.85 \pm 26.37 & -1.69 \pm 27.24 & -0.55 \pm 9.33 & -16.78 \pm 19.04 & \text { n.s. } \\ \text { day4 } & -18.40 \pm 18.36 & -25.07 \pm 30.69 & -7.33 \pm 13.43 & -22.68 \pm 17.14 & \\ \text { day7 } & -7.53 \pm 20.04 & -6.54 \pm 15.04 & -2.26 \pm 12.60 & -15.96 \pm 8.42 & \\ \text { day14 } & -17.15 \pm 22.53 & -1.44 \pm 25.68 & -17.62 \pm 15.81 & -10.45 \pm 16.30 & \\ \text { day22 } & -12.18 \pm 14.80 & -6.95 \pm 15.20 & -0.68 \pm 10.60 & -20.49 \pm 23.96\end{array}$

${ }^{1}$ From the mean of determined unidirectional Ca fluxes (Jms, fluxes from the mucosal to the serosal side; Jsm, fluxes from the serosal to the mucosal side), net flux of calcium was calculated by: Jnet $=\mathrm{Jms}-\mathrm{Jsm}\left(\mathrm{nmol} / \mathrm{h}\right.$ per $\left.\mathrm{cm}^{2}\right) ;{ }^{2}$ n.s., not significant $(\mathrm{P}>0.05) ;{ }^{3}$ compared to a diet high in DCAD and normal in Ca., effect only when DCAD is high and $\mathrm{Ca}$ is low; ${ }^{4}$ compared to $\mathrm{nCa} ;{ }^{5}$ compared to highDCAD;; ${ }^{6}$ compared to a diet high in DCAD and normal in Ca., effect only when DCAD is low and Ca is normal 


\section{Ussing Chamber Experiment}

Ruminal and jejunal net fluxes of $\mathrm{Ca}$ as associated with the different diets are presented in Table

7. While no associations of the different diets on unidirectional or net Ca absorption could be found in rumen, significant differences in jejunum were found. Indeed, mucoserosal Ca fluxes did not differ in the jejunum. LowCa was associated with higher seromucosal Ca fluxes in the Jejunum $(P=0.020)$. LowDCAD and lowCa were associated with higher jejunal Ca net fluxes $(P=0.003$ and $P<0.001$ resp.; Table 7). The associated increases of each dietary factor on jejunal Ca net fluxes were, however, weakened in interaction $(P=0.039)$.

\section{Apparent Digestibility}

Apparent digestibility of $\mathrm{Ca}$ was, compared to a diet high in DCAD and normal in $\mathrm{Ca}$, associated to be higher only when DCAD was low and Ca was normal $(P=0.027$; Table 7$)$. Apparent digestibility of PHOS was not associated with the different diets.

\section{RNA IQ and mRNA Abundance of renal and intestinal Ca regulating parameters (PCR)}

The RNA IQ of the isolated RNA was on average $8.97 \pm 1.38$ for the kidney samples (except the isolated RNA for determination of VDR in the kidney, which was $9.43 \pm 0.37), 9.34 \pm 0.41$ for the duodenal samples and $9.40 \pm 0.30$ for the jejunal samples.

The mRNA abundance of the analyzed receptors and proteins involved in $\mathrm{Ca}$ homeostasis as associated with the different diets are displayed in Table 8. Renal CaSR was, compared to a diet high in DCAD an normal in Ca, associated with a lower mRNA abundance only when DCAD and Ca were low $(P=0.010)$. Furthermore, lowCa and lowDCAD in interaction were associated with higher renal mRNA abundance levels of CYP27B1 $(P=0.032)$. LowDCAD was associated with a higher renal mRNA abundance of PTHR $(P<0.001)$. LowCa was associated with a higher jejunal TRPV5/6 mRNA abundance $(P=0.049)$. No differences in the mRNA abundance levels of CYP24A1, CaBPD28k, NCX1, TRPV5 and VDR could be found in the kidney. Additionally, no differences could be found for VDR in the duodenal and jejunal mucosa. 
Table 8. Effect of different diets on messenger Ribonucleic acid (mRNA) abundance of receptors and transport proteins in renal cortex resp. duodenal and jejunal mucosa (mean $\pm \mathrm{SE}$ ). Different sheep feeding groups received either a diet high or low in Dietary cation-anion difference (highDCAD/ lowDCAD) combined with normal or low Ca supply (nCa/ lowCa). mRNA abundance was normalized to a mean of 3 different reference genes: GAPDH (glyceraldehyde-3-phosphate dehydrogenase), $\beta$-actin, and RPS9 (Ribosomal protein S9). For statistical analysis, a lm resp. glm model gamma(log) family was used

\begin{tabular}{|c|c|c|c|c|c|c|}
\hline \multirow[b]{2}{*}{$\begin{array}{l}\text { Dependent } \\
\text { variable }\end{array}$} & \multicolumn{4}{|c|}{ Group (means \pm SE) } & \multirow[b]{2}{*}{ Independent variable } & \multirow[b]{2}{*}{$P$-value } \\
\hline & $\begin{array}{l}\text { highDCAD } \\
\mathrm{nCa}\end{array}$ & $\begin{array}{l}\text { highDCAD } \\
\text { lowCa }\end{array}$ & $\begin{array}{l}\text { lowDCAD } \\
\text { nCa }\end{array}$ & $\begin{array}{l}\text { lowDCAD } \\
\text { lowCa }\end{array}$ & & \\
\hline \multicolumn{7}{|l|}{ Renal cortex } \\
\hline $\mathrm{CaBP}_{\mathrm{D} 28 \mathrm{k}}{ }^{1}$ & $1.00 \pm 0.53$ & $0.90 \pm 0.52$ & $0.66 \pm 0.22$ & $0.84 \pm 0.11$ & n.s. ${ }^{10}$ & \\
\hline $\mathrm{CaSR}^{2}$ & $1.00 \pm 0.65$ & $1.03 \pm 0.47$ & $0.77 \pm 0.23$ & $0.38 \pm 0.26$ & lowDCADlowCa ${ }^{11}$ & 0.008 \\
\hline CYP24A1 ${ }^{3}$ & $1.00 \pm 0.49$ & $1.38 \pm 2.16$ & $0.83 \pm 0.50$ & $0.84 \pm 0.45$ & n.s. & \\
\hline CYP27B1 $1^{4}$ & $1.00 \pm 1.40$ & $0.50 \pm 0.50$ & $0.79 \pm 0.26$ & $2.51 \pm 1.51$ & lowDCAD*lowCa & 0.032 \\
\hline $\mathrm{NCX}^{5}$ & $1.00 \pm 0.40$ & $0.67 \pm 0.38$ & $0.67 \pm 0.37$ & $0.56 \pm 0.13$ & n.s. & \\
\hline PTHR $^{6}$ & $1.00 \pm 0.28$ & $0.93 \pm 0.28$ & $1.68 \pm 0.42$ & $1.94 \pm 0.93$ & lowDACD ${ }^{12}$ & $<0.001$ \\
\hline $\mathrm{TRPV}^{7}$ & $1.00 \pm 0.49$ & $0.58 \pm 0.22$ & $0.86 \pm 0.39$ & $0.94 \pm 0.20$ & n.s. & \\
\hline $\mathrm{VDR}^{8}$ & $1.00 \pm 0.20$ & $1.12 \pm 0.19$ & $1.13 \pm 0.22$ & $1.03 \pm 0.24$ & n.s. & \\
\hline \multicolumn{7}{|l|}{ Duodenum } \\
\hline $\mathrm{VDR}^{8}$ & $1.00 \pm 0.10$ & $0.86 \pm 0.11$ & $0.86 \pm 0.10$ & $0.96 \pm 0.24$ & n.s. & \\
\hline \multicolumn{7}{|l|}{ Jejunum } \\
\hline $\mathrm{VDR}^{8}$ & $1.00 \pm 0.16$ & $1.13 \pm 0.17$ & $0.80 \pm 0.30$ & $0.90 \pm 0.20$ & n.s. & \\
\hline TRPV5/6 ${ }^{9}$ & $1.00 \pm 0.96$ & $1.68 \pm 0.81$ & $1.34 \pm 0.91$ & $2.19 \pm 1.58$ & lowCa ${ }^{13}$ & 0.049 \\
\hline
\end{tabular}


${ }^{1} \mathrm{CaBPD} 28 \mathrm{k}$, calbindin D28k; ${ }^{2} \mathrm{CaSR}$, calcium-sensing receptor; ${ }^{3} \mathrm{CYP} 24 \mathrm{~A} 1,24-\mathrm{OH} a \mathrm{se} ;{ }^{4} \mathrm{CYP} 27 \mathrm{~B} 1,1 \alpha-\mathrm{OHase}$; ${ }^{5} \mathrm{NCX} 1$, sodium/Ca exchanger type 1; ${ }^{6} \mathrm{PTHR}$, parathyroid hormone receptor; ${ }^{7} \mathrm{TRPV} 5$, transient receptor potential vanilloid type 5; ${ }^{8} \mathrm{VDR}$, vitamin D receptor; ${ }^{9} \mathrm{TRPV} 5 / 6$, transient receptor potential vanilloid type 5 and $6 ;{ }^{10}$ n.s., not significant $(\mathrm{P}>0.05) ;{ }^{11}$ compared to a diet high in DCAD and normal in Ca., effect only when $\mathrm{DCAD}$ and $\mathrm{Ca}$ are low; ${ }^{12}$ compared to highDCAD; ${ }^{13}$ compared to $\mathrm{nCa}$ 


\section{DISCUSSION}

\section{Animal model}

In order to induce metabolic acidosis and effectively control hypocalcaemia, various urinary $\mathrm{pH}$ values in the range of 5.5 and 7.0 have been recommended for cows (Jardon, 1995; Moore et al., 2000; Charbonneau et al., 2006). For sheep, experiments were carried out using urinary pH values in the range of 5.0 and 7.0 (Braithwaite 1972, Las et al., 2007, Liesegang et al., 2008). In this study a diet very low in DCAD was fed $(-300 \mathrm{mEq} / \mathrm{kg} \mathrm{DM})$ in order to investigate the underlying physiological mechanisms in a low number of animals under experimental conditions. The lowDCAD diets resulted in urinary $\mathrm{pH}$ values between 5.5-6.0 without affecting blood $\mathrm{pH}$. Alterations of Ca homeostasis could be shown by effects on both, ionized and total Ca. Although none of the results obtained indicated that the sheep suffered from clinical or subclinical hypocalcemia (serum $\mathrm{Ca}<2.0 \mathrm{mmol} / \mathrm{L}$; Bickhardt et al. 1998), the animals responded to the new diets with remarkable changes such as differences in urine $\mathrm{pH}$ levels and FE of $\mathrm{Ca}$, blood levels of iCa, serum levels of total $\mathrm{Ca}$, mRNA abundance of PTHR, and $\mathrm{AD}$ of $\mathrm{Ca}$. Thus, we find that this animal model was appropriate to study basic effects of DCAD and to test our hypotheses, which are discussed below. However, the results presented may not necessarily be transferable to female reproducing sheep or other species, but can be seen as a first step to address the basic physiological pathways correlated with these feeding regimes in order to understand their effects in the prevention of milk fever in other animals such as dairy cows where milk fever is of greater economic interest.

\section{Transporter mediated renal Ca excretion}

While other species, such as rats easily adapt to very low Ca diets by increasing apparent absorption, diminishing renal Ca excretion, and enhancing renal PHOS excretion (Zhang et al., 2008), there are no comparable effects of a dietary Ca restriction on renal Ca or PHOS excretion reported in ruminants (Martz et al., 1999; Taylor et al., 2009; Wilkens et al., 2010; 2012). These 
findings could be verified in the current study. Despite differences in serum 1,25vitD concentrations, the lowCa diets did not result in a compensatory upregulation of TRPV5 and $\mathrm{CaBP}_{\mathrm{D} 28 \mathrm{~K}}$ in renal tissue, which has been reported for monogastric animals (Hoenderop et al., 2002; Ko et al., 2009).

An increase in urinary $\mathrm{Ca}$ excretion associated with low DCAD was evident in the present trial. As urinary $\mathrm{Ca}$ concentration could be diminished by an EDTA infusion in cows kept on an anion-rich diet, Schonewille et al. (1999) concluded that the large amounts of Ca excreted via the kidney represent a surplus that can be used when Ca homeostasis is challenged. In the present study, the increased excretion of $\mathrm{Ca}$ in urine/ FE of $\mathrm{Ca}$ was nearly independent of the dietary $\mathrm{Ca}$ intake indicating that renal $\mathrm{Ca}$ excretion is an unregulated process under these conditions. An inhibitory effect on tubular $\mathrm{Ca}$ absorption in acidotic states has been postulated (Yeh et al., 2003). In fact, further research reports that TRPV5 is only half as effective in a state of metabolic acidosis as it is in normal states (Suzuki et al., 2008). In the present study, the TRPV5 mRNA abundance in the kidney was not affected by the different diets supporting the hypothesis that the activity of TRPV5 rather than the abundance was influenced by low DCAD.

\section{Ca mobilization from bone}

In the present study, the pQCT analysis of sheep metatarsi revealed changes in BMD in all groups due to a physiological aging or growing process in the young sheep (Liesegang et al., 2013). At no point in time, differences between the groups were observed. In addition, intensive bone monitoring was carried out throughout the experiment by measuring specific bone parameters in the serum. SCL and OC are both proteins that are released during bone resorption and bone formation, respectively, and have been established as suitable markers for several animal species in previous studies (Liesegang et al., 1998; 2000; Russell, 2001; Liesegang and Risteli, 2005). The SCL, indicating enhanced osteoclast activity, increased during the trial with lowCa, but not with lowDCAD. Interestingly, the lowDCAD diets seemed to reduce serum concentrations of $\mathrm{OC}$, which suggests decreased bone formation, while dietary $\mathrm{Ca}$ does not 
exert any effects on this parameter. Bone tissue is involved in maintaining acid-base balance (Krieger et al., 2004), probably mediated by a proton sensing receptor expressed in osteoblasts, osteoclasts and osteocytes (Jorgetti et al., 2016). Chronic metabolic acidosis induced by $\mathrm{NH}_{4} \mathrm{Cl}$ administration in rats resulted in reduced plasma OC concentrations and an increase in plasma TRAP5c activity indicating enhanced bone mobilization (Gasser et al., 2014). The observation that only bone formation seemed to be affected by the metabolic acidosis in our study might be related to the rather moderate challenge of acid-base balance. The increase in bone resorption with the lowCa diets is probably mediated by a rise in PTH that also explains the stimulated production of $1,25 \mathrm{vitD}_{3}$. The additive effects of the two factors $\mathrm{Ca}$ and DCAD are represented by the bone turnover rate that was numerical highest in the lowDCADlowCa group. In contrast to these findings, changes of BMD and CBT were not evident. Increased bone turnover rates normally lead to reduced bone mineral content (Lips and van Schoor, 2011). The fact that only the metatarsus was measured by pQCT is a possible explanation for these conflicting results between pQCT and bone marker analysis (Liesegang, 2008), as bone markers show the turnover of the whole skeleton. Additionally, due to the temporal shift in the occurrence of changes in bone, no differences might have been detected in pQCT.

\section{PTH sensitivity and vitamin D metabolism}

A diet highly positive in DCAD reduced the renal sensitivity of PTHR to PTH in cows (Gaynor et al., 1989; Goff et al., 1991), while cows fed a negative DCAD diet responded better to exogenous PTH (Goff et al., 2014). It has been discussed that metabolic alkalosis results in a condition of pseudo hypoparathyroidism caused by a change in the tertiary structure of the PTH receptor-G-protein complex and a reduction in its affinity for PTH (Goff et al., 2014). In the present study, renal PTHR abundance was clearly stimulated by low DCAD at the mRNA level while dietary Ca had no effect as previously reported (Herm et al., 2015). An acidosis associated increase in PTHR RNA expression and affinity of the receptor to PTH was shown in vitro in osteoblast-like cells and in the renal cortex of cattle (Disthabanchong et al., 2002; Rodriguez et 
al., 2016). Interestingly, renal CaSR mRNA abundance was lower in the lowDCADlowCa group. On the one hand, PTH and 1,25vitD can modulate the expression of the CaSR. On the other hand, CaSR activation interferes with renal responses to 1,25vitD and PTH (Riccardi and Brown, 2010). As the plasma concentration of Ca determined via the CaSR can directly inhibit the synthesis of 1,25vitD (Bushinsky et al., 1985), a downregulation of CaSR might lead to a desensitization towards plasma $\mathrm{Ca}$ and thus favor the activation of 1,25vitD production. This assumption is supported by the observation that the CYP27B1 mRNA abundance was significantly increased by the interaction of low DCAD and low Ca. Of course, 1,25vitD plasma concentrations were also increased in the highDCADlowCa group (1.8fold), but the rise was numerically more pronounced in the lowDCADlowCa group (2.7fold). Unfortunately, PTH itself was not measured because there is no reliable test kit for sheep on the market. But the fact that 1,25 vitD was stimulated only by lowCa, and not by lowDCAD, indicates that PTH secretion was not induced by lowDCAD.

\section{Gastrointestinal Ca absorption}

Different in vitro and in vivo studies presented very well the essential role of ruminal $\mathrm{Ca}$ absorption in small ruminants. The role of ruminal $\mathrm{Ca}$ transport in vivo probably depends on $\mathrm{Ca}$ intake since an increase in Ca supply leads to increased preduodenal $\mathrm{Ca}$ net absorption in sheep and in cattle (Khorasani et al., 1997; Schroeder and Breves, 2006). We expected the rumen net flux rates to be increased by the low DCAD diets. Experiments presented in Wilkens et al. (2016) and Leonhard-Marek et al. (2007) led to the assumption that by diets low in DCAD apical transport systems are functionally changed due to alterations of surface and intracellular $\mathrm{pH}$ as other studies reported changes of ruminal epithelia due to the diet's energy content (Lodemann and Martens, 2006; Etschmann et al., 2009; Klevenhusen et al., 2013). However, ruminal flux rates were not affected by the different diets in the present study. It is important to note that in contrast to other studies (e.g., Wilkens et al., 2012, 2016) the animals were not fed before sacrifice, meaning that both the epithelium as well as the sample of rumen fluid were 
acquired long after the last feeding. This difference in the experimental design also explains the observation that rumen $\mathrm{Ca}$ concentrations were apparently not altered by dietary $\mathrm{Ca}$. It might be that the effects observed before are not as long-lasting as we expected them to be. The lack of any adaptation of the rumen epithelium to the dietary $\mathrm{Ca}$ content has been shown before (Wilkens et al., 2012). In the small intestine, a low dietary Ca content increased TRPV6 gene transcription and thus Ca transport probably via increased 1,25vitD (van Abel et al., 2003). In vitro experiments only give information on mechanistic aspects. In addition, Schroeder and Breves (2006) hypothesized a negative correlation between the net absorption in the forestomaches and the intestinal net absorption of $\mathrm{Ca}$ in cows as part of a compensatory effect. Therefore, we also addressed total tract digestibility in vivo.

Outcomes of different studies concerning the effect of lowDCAD diets on total apparent digestibility of $\mathrm{Ca}$ are inconsistent; while some studies report a higher apparent $\mathrm{Ca}$ digestibility with diets low in DCAD (Abu Damir et al., 1994; Schonewille et al., 1999; Roche et al., 2007), others found no or negative effects on apparent $\mathrm{Ca}$ digestibility or gastrointestinal $\mathrm{Ca}$ absorption when reducing the diet's DCAD (Leclerc and Block, 1989; Oehlschlaeger et al., 2014). These conflicting results could depend on the dietary formulation, particularly with regard to the dietary Ca supply. Positive effects of anionic diets on Ca absorption are expected only when the dietary Ca concentration is sufficient (Lomba et al., 1978; Wilkens et al., 2016).

Based on the findings mentioned above, we assumed an increase in apparent Ca digestibility to occur in group lowDCADnCa, but not in group lowDCADlowCa, which is consistent with our results. It is obvious that the calculated values of $\mathrm{AD}$ in this experiment are mostly negative. There were two sources of error in the calculation: on the one hand, an indicator method (ADL) was used to calculate the $\mathrm{AD}$. On the other hand, the faecal sample once a day represents only a snapshot. A total collection method of the faeces would only have been possible if the animals had been kept in metabolic cages, which could not be performed for animal welfare reasons. However, a comparison of the values obtained shows that $\mathrm{AD}$ of $\mathrm{Ca}$ was highest in group 
lowDCADnCa. As increased intestinal absorption indicated by the results on intestinal flux rates and gene abundance was observed with the low Ca but not with the low DCAD diets, we assume that the rumen contributed to the increased overall $\mathrm{AD}$ in the lowDCADnCa group although we were not able to prove an effect of the low DCAD feeding regime on rumen function in vitro.

\section{CONCLUSIONS}

The hypothesis that lowDCAD increases the FE of Ca regardless of dietary $\mathrm{Ca}$ intake was confirmed by this study. It is still unclear where the excess calcium that is excreted with lowDCAD in the urine comes from. Since no significant differences between the groups could be detected in the BMD, a significant bone participation in the Ca homeostasis of our sheep is unlikely. However, we can not exclude bone participation in the long term as bone marker analysis indicated. Our main hypothesis of an increased Ca net flux in the rumen could not be confirmed by this experiment. A significantly increased apparent Ca digestibility was shown in sheep that were fed lowDCADnCa. The jejunal Ca net fluxes in Ussing chamber were increased by both lowDCAD and lowCa. Mean serum $\mathrm{Ca}$ concentrations in group highDCADlowCa decreased slightly below the known reference range despite increased TRPV5/6 and jejunal Ca flux rates. Renal PTHR mRNA abundance, which is higher in groups with low DCAD, likely plays an important role in this process. Future studies should be conducted with female sheep or cows around parturition to verify whether the results shown can be reproduced under the influence of female sex hormones.

\section{ACKNOWLEDGEMENTS}

The authors thank Brigitta Wichert, Ines Mittner, Reto Mühlemann, Sonja Reinhardt and the entire team of the Institute of Animal Nutrition, Vetsuisse-Faculty Zürich, Switzerland for their excellent technical assistance and cooperation. Furthermore, authors are grateful for the cooperation of Kathrin Hansen and Karin Hustedt and the use of the lab and established methods from the Department for Physiology, University of Veterinary Medicine Hannover in 
these studies. The laboratory work was partly performed using the logistics of the Center of Clinical Studies at the Vetsuisse Faculty of the University of Zurich.

\section{CONFLICT OF INTEREST}

The authors declare no conflict of interest.

\section{REFERENCES}

Abu Damir, H., M. Phillippo, B. H. Thorp, J. S. Milne, L. Dick, and I. M. Inevison. 1994. Effects of dietary acidity on calcium balance and mobilisation, bone morphology and 1,25 dihydroxyvitamin D in prepartal dairy cows. Research in Veterinary Science. 56:310-318. https://doi.org/10.1016/0034-5288(94)90147-3.

Agroscope. 2016. Fütterungsempfehlungen für Wiederkäuer (Grünes Buch). Accessed Dec. 04, 2016. https://www.agroscope.admin.ch.

Block, E. 1984. Manipulating Dietary Anions and Cations for Prepartum Dairy Cows to Reduce Incidence of Milk Fever. Journal of dairy science. 67:2939-2948. https://doi.org/10.3168/jds.S0022-0302(84)81657-4.

Bickhardt K, P. Henze, A. Ganter. 1998. Clinical finding and differential diagnosis in ketosis and hypocalcaemia. Deutsche Tieräztliche Wochenschrift. 105(11):413-419.

Braithwaite, G. D. 1972. The effects of ammonium chloride on calcium metabolism in sheep. British Journal of Nutrition. 27:201. https://doi.org/10.1079/BJN19720083.

Brozos C., Mavrogianni V. S. and Fthenakis G.C. 2011. Treatment and control of periparturient metabolic diseases: pregnancy toxemia, hypocalcemia, hypomagnesemia. Veterinary Clinics of North America: Food Animal Practice 27:105-113. https://doi.org/10.1016/j.cvfa.2010.10.004.

Bushinsky, D. A., G. S. Riera, M. J. Favus, and F. L. Coe. 1985. Response of serum $1,25(\mathrm{OH}) 2 \mathrm{D} 3$ to variation of ionized calcium during chronic acidosis. The American journal of physiology. 249:F361-5. https://doi.org/10.1152/ajprenal.1985.249.3.F361.

Charbonneau, E., D. Pellerin, and G. R. Oetzel. 2006. Impact of Lowering Dietary CationAnion Difference in Nonlactating Dairy Cows: A Meta-Analysis. Journal of dairy science 89:537-548. https://doi.org/10.3168/jds.S0022-0302(06)72116-6.

Curtis, C. R., H. N. Erb, C. J. Sniffen, R. D. Smith, P. A. Powers, M. C. Smith, M. E. White, R. B. Hillman, and E. J. Pearson. 1983. Association of parturient hypocalcemia with eight periparturient disorders in Holstein cows. Journal of the American Veterinary Medical Association. 183:559-561. 
DeGaris, P. J., and I. J. Lean. 2008. Milk fever in dairy cows: a review of pathophysiology and control principles. The Veterinary Journal. 176:58-69. https://doi.org/10.1016/j.tvj1.2007.12.029.

Disthabanchong, S., K. J. Martin, C. L. McConkey, and E. A. Gonzalez. 2002. Metabolic acidosis up-regulates PTH/PTHrP receptors in UMR 106-01 osteoblast-like cells. Kidney international. 62:1171-1177. https://doi.org/10.1111/j.1523-1755.2002.kid568.x.

Elfers, K., G. Breves, A. S. Muscher-Banse. 2014. Modulation of aquaporin 2 expression in the kidney of young goats by changes in nitrogen intake. Journal of comparative physiology. B, Biochemical, systemic, and environmental physiology. 184: 929-936. https://doi.org/10.1007/s00360-014-0849-5.

Ender, F., I. W. Dishington, and A. Helgebostad. 1971. Calcium balance studies in dairy cows under experimental induction and prevention of hypocalcaemic paresis puerperalis. Zeitschrift fur Tierphysiologie, Tierernahrung und Futtermittelkunde. 28:233-256.

Etschmann, B., A. Suplie, and H. Martens. 2009. Change of ruminal sodium transport in sheep during dietary adaptation. Archives of animal nutrition. 63:26-38. https://doi.org/10.1080/17450390802506885.

Gasser, J. A., H. N. Hulter, P. Imboden, and R. Krapf. 2014. Effect of chronic metabolic acidosis on bone density and bone architecture in vivo in rats. American journal of physiology. Renal physiology. 306: F517-24. https://doi.org/10.1152/ajprenal.00494.2013.

Gaynor, P. J.; F. J. Mueller, J. K. Miller, N. Ramsey, J. P. Goff, and R. L. Horst. 1989. Parturient hypocalcemia in jersey cows fed alfalfa haylage-based diets with different cation to anion ratios. Journal of dairy science. 72:2525-2531. https://doi.org/10.3168/jds.S0022$\underline{0302(89) 79392-9 .}$.

Goff, J. P. 2008. The monitoring, prevention, and treatment of milk fever and subclinical hypocalcemia in dairy cows. The Veterinary Journal. 176:50-57. https://doi.org/10.1016/j.tvj1.2007.12.020.

Goff, J. P., R. L. Horst, F. J. Mueller, J. K. Miller, G. A. Kiess, and H. H. Dowlen. 1991. Addition of chloride to a prepartal diet high in cations increases 1,25-dihydroxyvitamin D response to hypocalcemia preventing milk fever. Journal of dairy science. 74:3863-3871. https://doi.org/10.3168/jds.S0022-0302(91)78579-2.

Goff, J. P., A. Liesegang, and R. L. Horst. 2014. Diet-induced pseudohypoparathyroidism: A hypocalcemia and milk fever risk factor. Journal of dairy science. 97:1520-1528. https://doi.org/10.3168/jds.2013-7467.

Goff, J. P., E. T. Littledike, and R. L. Horst. 1986. Effect of synthetic bovine parathyroid hormone in dairy cows: prevention of hypocalcemic parturient paresis. Journal of dairy science. 69:2278-2289. https://doi.org/10.3168/jds.S0022-0302(86)80666-X. 
Herm, G., A. S. Muscher-Banse, G. Breves, B. Schröder, and M. R. Wilkens. 2015. Renal mechanisms of calcium homeostasis in sheep and goats. Journal of animal science. 93:16081621. https://doi.org/10.2527/jas.2014-8450.

Hoenderop, J. G., O. Dardenne, M. van Abel, A. W. C. M. van der Kemp, C. H. van Os, R. StArnaud, and R. J. M. Bindels. 2002. Modulation of renal Ca2+ transport protein genes by dietary Ca2+ and 1,25-dihydroxyvitamin D3 in 25-hydroxyvitamin D3-1alpha-hydroxylase knockout mice. FASEB journal: official publication of the Federation of American Societies for Experimental Biology. 16:1398-1406. https://doi.org/10.1096/fj.02-0225com.

Horst, R. L., J. P. Goff, T. A. Reinhardt, and D. R. Buxton. 1997. Strategies for Preventing Milk Fever in Dairy Cattle1, 2. Journal of dairy science. 80:1269-1280. https://doi.org/10.3168/jds.S0022-0302(97)76056-9.

Jardon, P. W. 1995. Using urine $\mathrm{pH}$ to monitor anionic salt programs. Compendium of Continuing Education for the Practicing Veterinarian. 17:860-862.

Jorgetti, V., T. B. Drüeke, and S. M. Ott. 2016. Role of proton receptor OGR1 in bone response to metabolic acidosis? Kidney international. 89:529-531. https://doi.org/10.1016/j.kint.2015.12.031.

Kamphues J., M. Coenen, E. Kienzle, J. Pallauf, O. Simon, J. Zentek. 2004. Supplemente zu Vorlesungen und Übungen in der Tierernährung. 10th edn. M. und H. Schaper GmbH \& Co KG, Alfeld, Germany.

Khorasani, G. R., R. A. Janzen, W. B. McGill, J. J. Kennelly. 1997. Site and extent of mineral absorption in lactating cows fed whole-crop cereal grain silage of alfalfa silage. Journal of animal science. 75:239-248. https://doi.org/10.2527/1997.751239x.

Klevenhusen, F., M. Hollmann, L. Podstatzky-Lichtenstein, R. Krametter-Frötscher, J. R. Aschenbach, Q. Zebeli. 2013. Feeding barley grain-rich diets altered electrophysiological properties and permeability of the ruminal wall in a goat model. Journal of dairy science. 96: 2293-2302. https://doi.org/10.3168/jds.2012-6187.

Krieger, N. S., K. K. Frick, and D. A. Bushinsky. 2004. Mechanism of acid-induced bone resorption. Current Opinion in Nephrology and Hypertension. 13:423-436. https://doi.org/10.1097/01.mnh.0000133975.32559.6b.

Ko, S. H., G. S. Lee, T. T. B. Vo, E. M. Jung, K. C. Choi, K. W. Cheung, J. W. Kim, J. G. Park, G. T. Oh, and E. B. Jeung. 2009. Dietary calcium and 1,25-dihydroxyvitamin D3 regulate transcription of calcium transporter genes in calbindin-D9k knockout mice. The Journal of reproduction and development. 55:137-142. https://doi.org/10.1262/jrd.20139.

Lean, I. J., P. J. DeGaris, D. M. McNeil, and E. Block. 2006. Hypocalcemia in Dairy Cows: Meta-analysis and Dietary Cation Anion Difference Theory Revisited. Journal of dairy science. 89:669-684. https://doi.org/10.3168/jds.S0022-0302(06)72130-0.

Leclerc, H., and E. Block. 1989. Effects of reducing dietary cation-anion balance for prepartum dairy cows with specific reference to hypocalcemic parturient paresis. Canadian Journal of Animal Science. 69:411-423. https://doi.org/10.4141/cjas89-046. 
Leonhard-Marek, S., G. Becker, G. Breves, and B. Schroder. 2007. Chloride, gluconate, sulfate, and short-chain fatty acids affect calcium flux rates across the sheep forestomach epithelium. Journal of dairy science. 90:1516-1526. https://doi.org/10.3168/jds.S0022-0302(07)71637-5.

Liesegang, A. 2008. Influence of anionic salts on bone metabolism in periparturient dairy goats and sheep. Journal of dairy science. 91:2449-2460. https://doi.org/10.3168/jds.2006-838.

Liesegang, A., C. Chiappi, J. Risteli, J. Kessler, and H. D. Hess. 2007. Influence of different calcium contents in diets supplemented with anionic salts on bone metabolism in periparturient dairy cows. Journal of animal physiology and animal nutrition. 91:120-129. https://doi.org/10.1111/j.1439-0396.2006.00651.x.

Liesegang, A., R. Eicher, M.-L Sassi, J. Risteli, M. Kraenzlin, J.-L Riond, and M. Wanner. 2000. Biochemical Markers of Bone Formation and Resorption Around Parturition and During Lactation in Dairy Cows with High and Low Standard Milk Yields. Journal of dairy science. 83:1173-1781. https://doi.org/10.3168/jds.S0022-0302(00)75048-X.

Liesegang, A., D. Huttenmoser, J. Risteli, F. Leiber, M. Kreuzer, and M. Wanner. 2013. Influence of high-altitude grazing on bone metabolism of growing sheep. Journal of animal physiology and animal nutrition. 97:58-66. https://doi.org/10.1111/j.14390396.2011.01242.x.

Liesegang, A., and J. Risteli. 2005. Influence of different calcium concentrations in the diet on bone metabolism in dairy goats and sheep. Journal of animal physiology and animal nutrition. 89:113-119. https://doi.org/10.1111/j.1439-0396.2005.00548.x.

Liesegang, A., M.-L. Sassi, and J. Risteli. 2003. Diurnal variation in concentrations of various markers of bone metabolism in growing female goats and sheep. Animal Science. 77:197203. https://doi.org/10.1017/S1357729800058938.

Liesegang, A., M.-L. Sassi, J. Risteli, R. Eicher, M. Wanner, and J.-L. Riond. 1998. Comparison of Bone Resorption Markers During Hypocalcemia in Dairy Cows. Journal of dairy science. 81:2614-2622. https://doi.org/10.3168/jds.S0022-0302(98)75819-9.

Lips, P., and N. M. van Schoor. 2011. The effect of vitamin D on bone and osteoporosis. Best practice \& research. Clinical endocrinology \& metabolism. 25:585-591. https://doi.org/10.1016/j.beem.2011.05.002.

Lodemann, U., and H. Martens. 2006. Effects of diet and osmotic pressure on $\mathrm{Na}+$ transport and tissue conductance of sheep isolated rumen epithelium. Experimental physiology. 91:539-550. https://doi.org/10.1113/expphysiol.2005.032078.

Lomba, F., G. Chauvaux, E. Teller, L. Lengele, and V. Bienfet. 1978. Calcium digestibility in cows as influenced by the excess of alkaline ions over stable acid ions in their diets. British Journal of Nutrition. 39:425-429. https://doi.org/10.1079/BJN19780058.

Martinez, N., C. A. Risco, F. S. Lima, R. S. Bisinotto, L. F. Greco, E. S. Ribeiro, F. Maunsell, K. Galvão, and J. E. Santos. 2012. Evaluation of peripartal calcium status, energetic profile, and neutrophil function in dairy cows at low or high risk of developing uterine disease. Journal of dairy science. 95:7158-7172. https://doi.org/10.3168/jds.2012-5812. 
Martin-Tereso, J., and M. W. A. Verstegen. 2011. A novel model to explain dietary factors affecting hypocalcaemia in dairy cattle. Nutrition research reviews. 24:228-243. https://doi.org/10.1017/S0954422411000126.

Martz, F. A., A. T. Belo, M. F. Weiss, and R. L. Belyea. 1999. True absorption of calcium and phosphorus from corn silage fed to nonlactating, pregnant dairy cows. Journal of dairy science. 82:618-622. https://doi.org/10.3168/jds.S0022-0302(99)75275-6.

Moore, S. J., M. J. VandeHaar, B. K. Sharma, T. E. Pilbeam, D. K. Beede, H. F. Bucholtz, J. S. Liesman, R. L. Horst, and J. P. Goff. 2000. Effects of altering dietary cation-anion difference on calcium and energy metabolism in peripartum cows. Journal of dairy science. 83:2095-2104. https://doi.org/10.3168/jds.S0022-0302(00)75091-0.

Naumann, C., and R. Bassler. 1997. Die chemische Untersuchung von Futtermitteln, Methodenbuch Band III. VDLUFA Verlag, Darmstadt, Germany.

Nemeth, N. V., M. R. Wilkens, A. Liesegang. 2017. Vitamin D status in growing dairy goats and

sheep: Influence of ultraviolet B radiation on bone metabolism and calcium homeostasis. Journal of Dairy Science. 100: 8072-8086. https://doi.org/10.3168/jds.2017-13061.

Oehlschlaeger, V., M. R. Wilkens, B. Schroeder, S. Daenicke, and G. Breves. 2014. Effects of 25-hydroxyvitamin D3 on localisation and extent of gastrointestinal calcium absorption in dairy cattle. Animal Production Science. 54:1394-1398. https://doi.org/10.1071/AN14344.

Oetzel, G. R. 1988. Parturient paresis and hypocalcemia in ruminant livestock.

Veterinary Clinics of North America: Food Animal Practice. 4:351-364. https://doi.org/10.1016/S0749-0720(15)31053-7.

Pugh, D. G. 2002. Sheep and Goat Medicine. 1st edn. W. B. Saunders Company, Philadelphia, USA.

Riccardi, D., and E. M. Brown. 2010. Physiology and pathophysiology of the calcium-sensing receptor in the kidney. American journal of physiology. Renal physiology. 298: F485-99. https://doi.org/10.1152/ajprenal.00608.2009.

Roche, J. R., D. E. Dalley, and F. P. O'Mara. 2007. Effect of a metabolically created systemic acidosis on calcium homeostasis and the diurnal variation in urine $\mathrm{pH}$ in the non-lactating pregnant dairy cow. Journal of Dairy Research. 74:34-39. https://doi.org/10.1017/S0022029906002123.

Rodriguez, E. M., A. Bach, M. Devant, and A. Aris. 2016. Is calcitonin an active hormone in the onset and prevention of hypocalcemia in dairy cattle? Journal of dairy science. 99:30233030. https://doi.org/10.3168/jds.2015-10229.

Russell, G. 2001. Bone metabolism and its regulation. In Bone Markers. R. Eastell, M. Baumann, N. R. Hoyle, L. Wiecorek, ed. M. Dunitz Ltd., London, UK. 1-26.

Sacco, R.E., B. J. Nonnecke, M. V. Palmer, W. R. Waters, J. D. Lippolis, T. A. Reinhardt. 2012. Differential expression of cytokines in response to respiratory syncytial virus infection of 
calves with high or low circulating 25-hydroxyvitamin D3. PloS one 7, e33074. https://doi.org/10.1371/journal.pone.0033074.

Schonewille, J. T., A. T. Van’t Klooster, H. Wouterse, and A. C. Beynen. 1999. Hypocalcemia Induced by Intravenous Administration of Disodium Ethylenediaminotetraacetate and its Effects on Excretion of Calcium in Urine of Cows Fed a High Chloride Diet. Journal of dairy science. 82:1317-1324. https://doi.org/10.3168/jds.S0022-0302(99)75355-5.

Schroeder, B., and G. Breves. 2006. Mechanisms and regulation of calcium absorption from the gastrointestinal tract in pigs and ruminants: comparative aspects with special emphasis on hypocalcemia in dairy cows. Animal health research reviews. 7:31-41. https://doi.org/10.1017/S1466252307001144.

Sidler-Lauff, K., A. Boos, M. Kraenzlin, A. Liesegang. 2010. Influence of different calcium supplies and a single vitamin D injection on vitamin D receptor and calbindin D9k immunoreactivities in the gastrointestinal tract of goat kids. Journal of animal science. 88: 3598-3610. https://doi.org/10.2527/jas.2009-2682.

Stangl, G. I. 2014. Die Verdauung. In Tiernährung. 14th edn. M. Kirchgessner, G. I. Stangl, F. J. Schwarz, F. X. Roth, K. H. Südekum, K. Eder (eds.). DLG-Verlag GmbH, Frankfurt am Main, Germany. 27-46.

Suzuki, Y., C. P. Landowski, M. A. Hediger. 2008. Mechanisms and Regulation of Epithelial Ca 2+ Absorption in Health and Disease. Annual Review of Physiology. 70:257-271. https://doi.org/10.1146/annurev.physiol.69.031905.161003.

Taylor, M. S., K. F. Knowlton, M. L. McGilliard, W. S. Swecker, J. D. Ferguson, Z. Wu, and M. D. Hanigan. 2009. Dietary calcium has little effect on mineral balance and bone mineral metabolism through twenty weeks of lactation in Holstein cows. Journal of dairy science. 92: 223-237. https://doi.org/10.3168/jds.2008-1345.

Tschuor, A., B. Riond, U. Braun, and H. Lutz. 2008. Hämatologische und klinisch-chemische Referenzwerte für adulte Ziegen und Schafe. Schweizer Archiv fuer Tierheilkunde. 150:287295. https://doi.org/10.1024/0036-7281.150.6.287.

van Abel, M., J. G. J. Hoenderop, A. W. van der Kemp, J. P. van Leeuwen, and R. J. Bindels. 2003. Regulation of the epithelial $\mathrm{Ca} 2+$ channels in small intestine as studied by quantitative mRNA detection. American journal of physiology. Gastrointestinal and liver physiology. 285:G78-85. https://doi.org/10.1152/ajpgi.00036.2003.

van Soest, P. J., J. B. Robertson, B. A. Lewis. 1991. Methods for Dietary Fiber, Neutral Detergent Fiber, and Nonstarch Polysaccharides in Relation to Animal Nutrition. Journal of dairy science. 74:3583-3597. https://doi.org/10.3168/jds.S0022-0302(91)78551-2.

Venjakob, P. L., S. Borchardt, and W. Heuwieser. 2017. Hypocalcemia - Cow-level prevalence and preventive strategies in German dairy herds. Journal of dairy science. 100:9258-9266. https://doi.org/10.3168/jds.2016-12494. 
Wang, C., and D. K. Beede. 1992. Effects of ammonium chloride and sulfate on acid-base status and calcium metabolism of dry Jersey cows. Journal of dairy science. 75:820-828. https://doi.org/10.3168/jds.S0022-0302(92)77821-7.

Wilkens, M. R., N. Mrochen, G. Breves, and B. Schroeder. 2011. Gastrointestinal calcium absorption in sheep is mostly insensitive to an alimentary induced challenge of calcium homeostasis. Comparative biochemistry and physiology. Part B, Biochemistry \& molecular biology. 158:199-207. https://doi.org/10.1016/j.cbpb.2010.11.008.

Wilkens, M. R., C. Kunert-Keil, H. Brinkmeier, and B. Schröder. 2009. Expression of calcium channel TRPV6 in ovine epithelial tissue. The Veterinary Journal. 182:294-300. https://doi.org/10.1016/j.tvj1.2008.06.020.

Wilkens, M. R., N. Mrochen, G. Breves, and B. Schröder. 2010. Effects of 1,25dihydroxyvitamin D3 on calcium and phosphorus homeostasis in sheep fed diets either adequate or restricted in calcium content. Domestic animal endocrinology. 38:190-199. https://doi.org/10.1016/j.domaniend.2009.10.003.

Wilkens, M. R., C. Praechter, G. Breves, and B. Schröder. 2016. Stimulating effects of a diet negative in dietary cation-anion difference on calcium absorption from the rumen in sheep. Journal of animal physiology and animal nutrition. 100:156-166. https://doi.org/10.1111/jpn.12296.

Wilkens, M. R., J. Richter, D. R. Fraser, A. Liesegang, G. Breves, and B. Schröder. 2012. In contrast to sheep, goats adapt to dietary calcium restriction by increasing intestinal absorption of calcium. Comparative biochemistry and physiology. Part A, Molecular \& integrative physiology. 163:396-406. https://doi.org/10.1016/j.cbpa.2012.06.011.

Wilkens, M. R., J. Richter, D. R. Fraser, A. Liesegang, G. Breves, and B. Schröder. 2012. In contrast to sheep, goats adapt to dietary calcium restriction by increasing intestinal absorption of calcium. Comparative biochemistry and physiology. Part A, Molecular \& integrative physiology. 163:396-406. https://doi.org/10.1016/j.cbpa.2012.06.011.

Xie, F., P. Xiao, D. Chen, L. Xu, B. Zhang. 2012. miRDeepFinder: a miRNA analysis tool for deep sequencing of plant small RNAs. Plant molecular biology 80 (1), 75-84. https://doi.org/10.1007/s11103-012-9885-2.

Yeh, B. I., T. J. Sun, J. Z. Lee, H. H. Chen, C. L. Huang. 2003. Mechanism and molecular determinant for regulation of rabbit transient receptor potential type 5 (TRPV5) channel by extracellular pH. The Journal of biological chemistry. 278:51044-51052. https://doi.org/10.1074/jbc.M306326200.

Zhang, Y., W.-P. Lai, P.-C. Leung, C.-T. Che, and M.-S. Wong. 2008. Improvement of Ca balance by Fructus Ligustri Lucidi extract in aged female rats. Osteoporosis international: a journal established as result of cooperation between the European Foundation for Osteoporosis and the National Osteoporosis Foundation of the USA. 19:235-242. https://doi.org/10.1007/s00198-007-0442-9. 


\section{Danksagung}

An dieser Stelle möchte mich bei allen herzlich bedanken, die zum Gelingen dieser Arbeit beigetragen haben und mit deren Unterstützung ich jederzeit rechnen konnte:

Prof. Dr. med. vet. A. Liesegang für das Bereitstellen des Themas, die fachliche und praktische Unterstützung, die gewissenhafte Durchsicht dieser Arbeit und die gute Zusammenarbeit.

Prof. Dr. med. vet. Mirja Wilkens, Dr. rer. nat. Alexandra Muscher-Banse und dem Institut für Physiologie und Zellbiologie der Tierärztlichen Hochschule Hannover (insbes. Nadine Schnepel, Karin Hustedt und Kathrin Hansen): Für die gute Betreuung und Kooperation, die fachliche Unterstützung, das Bereitstellen des Labors und der Hannoveraner Methoden, das Einlernen und die Unterstützung bei der Durchführung der PCRs, sowie die gewissenhafte Durchsicht dieser Arbeit.

Dr. med. vet. Kerstin Gerstner und PD Dr. med. vet. Brigitta Wichert für die Planung des Versuchs, die Einführung in die Versuchsdurchführung und die intensive Betreuung während des Versuchs.

Prof. Dr. med. vet. Paul Torgerson für die intensive fachliche Unterstützung beim statistischen Teil dieser Arbeit.

Ines Mittner, Reto Mühlemann und Sonja Reinhard für die Durchführung der umfangreichen Laborarbeiten, für ihre Geduld und ihre Unterstützung.

Besonderer Dank geht auch an das Team für Tierernährung, insbesondere an Angela Gimmel, Camilo Ernesto Pardo, Holger Born, Niklas Karst, Rahel Rigotti, Tamara Seghers, Clarissa Jung für die tatkräftige Unterstützung bei der Versuchsdurchführung, insbesondere der frühmorgendlichen Probennahmen und die allzeitige Hilfsbereitschaft. Ebenso an die Metzger Paul Müller und Harald Gabriel für die Ermöglichung der Probennahmen im Schlachtlokal und an meine Familie und meinem Freund, die immer an mich geglaubt haben. 


\section{Curriculum Vitae}

Vorname, Name

Geburtsdatum

Geburtsort

Nationalität

08/1998 - 07/2002

08/2002-07/2011

$17 / 06 / 2011$

10/2011-02/2017

$14 / 02 / 2017$

03/2017 - 06/2019

03/2017-06/2021

09/2019-01/2020

$06 / 2020$ - heute
Johanna Rosa Berndine Freitag

27.01.1992

Vechta

Deutsch

Grundschule Rechterfeld, Rechterfeld, Deutschland

Liebfrauenschule Vechta, Gymnasium, Vechta,

Deutschland

Abitur, Liebfrauenschule Vechta, Gymnasium, Vechta,

Deutschland

Studium der Veterinärmedizin, Justus-Liebig-Universität

Gießen, Gießen, Deutschland

Abschlussprüfung vet. med. und Approbation, Justus-

Liebig-Universität Gießen, Gießen, Deutschland

Doktorandin am Institut für Tierernährung und Diätetik der

Vetsuisse-Fakultät Universität Zürich, Schweiz

Anfertigung der Dissertation

unter Leitung von Prof. Dr. med. vet. Annette Liesegang

am Institut für Tierernährung und Diätetik

der Vetsuisse-Fakultät Universität Zürich

Direktorin: Prof. Dr. med. vet. Annette Liesegang

General farm worker, Nicomekl Farms Ltd., Cloverdale, Kanada

Tierärztin, Tierarztpraxis Dr. Nufer, Meiringen, Schweiz 